\title{
Competition Under Credit Rationing: Theory and Evidence from Rural China*
}

\author{
Albert Park \\ Department of Economics, University of Michigan \\ Loren Brandt \\ Department of Economics, University of Toronto \\ John Giles \\ Department of Economics, Michigan State University
}

May 2002

\begin{abstract}
We present a duopoly model of financial competition to describe the conditions under which competition leads to greater bank effort when repressed financial systems ration credit. The model features an entrant that freely sets its interest rate and an incumbent that must charge a rate below that which is market clearing. Both players may exert costly effort to inform themselves about borrower types. Using data on rural financial institutions in China, we test empirically the effects of competition on deposit growth, loan portfolio composition, repayment rates, and other effort measures, finding positive effects of competition on effort and financial performance.

JEL Codes: O16, G28, P34, O53

Key words: banking, competition, credit, rationing, China

Correspondence author: Albert Park, Department of Economics, University of Michigan, Ann Arbor, MI 48109-1220, tel: 734-764-2363, fax: 734-764-2769, email: alpark@umich.edu

*We acknowledge Ford Foundation and Rockefeller Foundation for supporting the field research. Thanks to John Bonin, Serdar Dinc, Roger Gordon, Kai-Uwe Kuhn, David Li, Rohini Somanathan, Xiaodong Zhu, and seminar participants at the University of Michigan, University of Toronto, and Academia Sinica (Taiwan).
\end{abstract}




\section{Competition Under Credit Rationing: Theory and Evidence from Rural China}

\section{Introduction}

Strategic pricing of the interest rate is a central feature of models of competition among financial institutions (Dinc, 2000; Villas-Boas and Schmidt-Mohr, 1999; Peterson and Rajan, 1995; Riordan, 1993; Besanko and Thakor, 1993 and 1987). ${ }^{1}$ In many countries, however, especially developing ones, financial markets remain highly regulated. Interest rates are set by the government, typically below market-clearing levels, and inter-bank lending is restricted. In such environments, banks are limited in their ability to price and lend strategically, so that the effects of competition may be different. In financially repressed systems, a natural tendency arises for alternative institutions to emerge to meet the credit needs of excluded borrowers. Most of the existing literature describes such markets as segmented. However, in many instances, alternative institutions also compete directly with existing banks for deposits and borrowers. Such competitors (e.g., private banks, credit cooperatives, rotating savings and credit associations--ROSCAs, moneylenders) often are not subject to the same interest rate controls as formal financial institutions or find ways to circumvent restrictions. Their presence may affect the behavior, profitability, and intermediation role of incumbent banks.

Surprisingly there is little theory or empirical evidence on competition under this type of credit rationing, despite its widespread prevalence (especially in developing countries) and obvious implications for optimal regulation of competition. hand, competition may improve financial intermediation by providing a diversity of institutional strengths that can better meet the needs of different demand groups and by putting greater pressure on existing banks to innovate and reform (Classen, 1997). This reform incentive may be particularly important for transition economies whose goal is to move to modern financial systems, or for the many other countries with poorly performing banking systems. On the other hand, regulators may consider competition a threat to control of the financial system - control that is necessary to prudentially regulate banks, to maintain macroeconomic stability, and to direct financial resources to targeted 
groups. Competitors divert resources and undermine the profitability of state banks. Monopoly pricing is not a concern because of strict regulation. Models of bank competition in unregulated environments find ambiguous welfare effects of competition (Dinc, 2000; Villas-Boas and Schmidt-Mohr, 1999; Peterson and Rajan, 1995; Riordan, 1993; Besanko and Thakor, 1993 and 1987).

Many of the important policy debates over financial system reform in China are related to views on the effects of financial competition. The Chinese government in most instances has tolerated the emergence of competing institutions at local levels, especially if they harness new financial resources, but has sought to coopt and regulate them once they reached a large scale and drew funds from state financial institutions. Examples include conversion of urban cooperatives into Urban Cooperative Banks in 1997, the dissolution of rapidly expanding Rural Cooperative Foundations (RCFs) in rural areas in 1999, and the closure of numerous Trust and Investment Companies (TICs) in 1999. These anti-competitive policies and others ${ }^{3}$ are motivated by the high priority placed by government on control over financial resources under a system that continues to steer much formal credit to state-owned enterprises. ${ }^{1}$ Reformers nonetheless have stressed the importance of competition and local institutional innovation to improved economic performance. ${ }^{\text {In }}$ the industrial sector, competition between state and non-state firms was credited with improving incentives and performance despite slow ownership reform (Naughton and McMillan, 1992). However in that case, open competition was accompanied by partial price liberalization through the dual-track pricing system.

In this paper, we develop a simple model of financial competition under credit rationing caused by financial regulation to illustrate the possible outcomes of competition when financial systems are repressed, and then present evidence on the effect of such competition in rural China. Our model treats competition as a duopoly game between an incumbent and an entrant in which the entrant can freely set the interest rate but the incumbent must charge a rate below that which is market clearing. Both players may exert costly effort to inform themselves about borrower types. We describe the possible effects of competition, finding that competition will reduce inefficient credit rationing 
and that effect of competition on incumbent effort depends on the entrant's market share and the extent of credit rationing absent competition.

Rural China provides a unique natural experiment for studying the effect of financial competition on economic performance. Geographic mobility of financial institutions in rural China was highly restricted through the mid-1980s, with regulated Rural Credit Cooperatives (RCCs) dominating local markets for deposits and loans to rural households and enterprises. Beginning in the late 1980s, a new and dynamic financial institution emerged in some rural areas. Rural Cooperative Foundations (RCFs) were quasi-state organizations under the administrative supervision of the Ministry of Agriculture. Lacking legal status as financial institutions, RCFs were often allowed to provide effective interest rates on loans and deposits that exceeded official rates. They received official endorsement by China's State Council in 1986 and grew rapidly in some parts of the country, with funds reaching about 100 billion yuan nationally by year-end 1996 compared to 880 billion yuan in RCC deposits (Cheng, Findlay, and Watson, 1997). In September of 1996, RCFs existed in 38 percent of all Chinese townships (Du, 1998).

RCF entry into previously uncontested markets and the effect of that entry on the performance of RCCs provides an unusually clean story of financial competition. While the entry decision of RCFs is endogenous, it is a decision that can be modeled and identified by data describing economic conditions before entry. Differences in the timing of RCF entry in different provinces provide additional exogenous variation. Thus we can take advantage of spatial and temporal variation in RCF entry to identify the effect of RCF competition on aspects of RCC performance-- deposit growth, loan portfolio composition, repayment rates, and institutional effort. These effects were at the center of the policy debate over RCF regulation (Holz, 2001). Did RCFs simply steal deposits and reduce the profitability of RCCs, or did they deepen financial intermediation by mobilizing new deposits and improving loan performance, both through their own screening and enforcement effort, and by providing RCCs with competitive pressure to reform?

The paper is divided into two main sections - theoretical and empirical. In the former, we consider the monopolist's problem, develop a model of competition under 
credit rationing, and discuss equilibrium strategies and the effect of competition on effort under different scenarios. In the latter, we introduce China's rural financial institutions and our data set, present empirical estimates of the location decision of RCFs and the effect of competition on RCC performance, and interpret the results. In the concluding section, we discuss policy implications.

\section{Modeling Competition Under Credit Rationing}

Rationing in our model is caused by regulated interest rates set below marketclearing levels, which leads to excess demand for loans. In this environment, we first consider the problems of borrowers and lender in the non-competitive, or monopoly case. We then consider what happens when there is an entrant, describing the possible outcomes of a duopoly model given different effort choices of the incumbent and entrant. We compare the return to effort by the incumbent with and without entry to assess whether competition is likely to improve the effort and performance of incumbent banks.

The model makes several key assumptions. The first is that interest rate controls are strictly enforced. Although banks can evade interest rate controls through compensating deposit balances or by charging non-interest fees, we argue that regulatory enforcement significantly circumscribes such practices. We appeal to the large literature documenting "financial repression" in many developing countries, which presumes binding interest rate restrictions (Fry, 1995; McKinnon, 1973); the frequent complaints of managers in China that low interest rates undermine profitability (supported by evidence of substantial losses); and the watchdog role of local government officials in China, whose interests are allied with collective enterprises, the primary rural borrowers. In China, financial institutions are only allowed to set interest rates within a narrow range with strict upper and lower bounds.

A second important regulatory feature is limits on interbank lending, which strictly ties lending volume to the amount of deposits. China placed severe restrictions on the inter-bank market beginning in 1993, and lending by rural credit cooperatives has been closely tied to the amount of deposits held (Park and Sehrt, 2001; Shen, 2000). 
The model intentionally overlooks the possibility that higher interest rates can lead to moral hazard and adverse selection problems when borrowers do not bear full responsibility for downside risk (Stiglitz and Weiss, 1981; Carter, 1988). Such concerns can lead to "equilibrium credit rationing" in which banks prefer to ration credit rather than raise the interest rate even when interest rates are not regulated. While this phenomena is important in many settings, in financially repressed systems, real interest rates remain well below those characterized by equilibrium credit rationing. In China, real interest rates in the mid-1990s were negative in real terms in an economy in which real GDP was growing at over 10 percent per year. ${ }^{6}$ In such an environment, our results on the effects of competition should be relevant even if moral hazard and adverse selection limit the interest rates entrants are willing to charge or affect the desirability of lending. Effort could also increase at higher interest rates to combat agency problems. These possibilities should be taken into account in the empirical analysis, but do not alter the main theoretical results, especially for effort by incumbent banks, which by assumption cannot alter the interest rate.

Our problem has similarities to the cream skimming problem in which preferred customers of a regulated monopoly have access to an alternative supplier (Laffont and Tirole, 1993). Nonetheless, there are important differences. Laffont and Tirole's model presumes firms cannot know customer types or exert effort but can practice second degree price discrimination, i.e. charge different prices for different quantities. In our model, managers can learn about borrower types, and cannot price discriminate (incumbents cannot even set prices). One relevant lesson from this literature is that regulators may have an interest in regulating competition when there are high fixed costs to production. We discuss this point below.

\section{Borrower's Problem}

Assume that the size of loans are normalized to one. All potential borrowers take out a loan and invest in a project with potential return y. Borrowers differ only in the probability that the project is successful $\left(\theta_{\mathrm{i}}\right.$, or the borrower's type $)$, which is known to the borrower but initially unknown to the bank. If the project is unsuccessful, the return 
is zero and the borrower defaults on the loan. All loans are invested in the project-we do not consider moral hazard.

The borrower must pay a fixed cost $\eta$ to apply for a loan, which makes uncertainty over loan approval costly to the borrower. The cost to uncertainty formalizes the importance of reliability, or a high probability of loan application approval, to customers, especially critical when credit is rationed. To simplify, we assume that the application cost is fixed and the same for all lenders. ${ }^{\square}$

The expected return $\left(E \pi_{B}{ }^{i j}\right)$ for borrower $i$ who applies for a loan from bank $j$ is the following:

$$
\begin{gathered}
E \pi_{B}^{i j}=\gamma_{j} \theta_{i}\left(y-R_{j}\right)-\eta \quad \text { if } \theta_{i}>\frac{\eta}{\gamma_{j}\left(y-R_{j}\right)} \\
E \pi_{B}^{i j}=0 \quad \text { if } \theta_{i} \leq \frac{\eta}{\gamma_{j}\left(y-R_{j}\right)} .
\end{gathered}
$$

Expected profit from applying for a loan depends on the probability of receiving a loan $\left(\gamma_{j}\right)$ from lender $j$, the probability that the project will be successful $\left(\theta_{i}\right)$, and the expected return from the project given the interest payment $R_{j}$. If the borrower has a very low probability of success, he may decide not to apply for the loan, in which case his profit is zero. Otherwise, the borrower applies to the bank which maximizes his expected return. If the expected returns are identical, he picks one of the banks randomly. Equation (1) shows that 1) loan demand depends on the probability of receiving a loan, the quality of the project, the interest rate, and the application cost; and 2) the factors affecting the decision on which bank to apply to for a loan are the likelihood of getting a loan and the interest rate.

We define the function $\mathrm{G}(\theta)=1-\mathrm{F}(\theta)$, where $\mathrm{F}(\theta)$ is the cumulative distribution function for types in the population. When there is a single bank, the size of the pool of applicants can be expressed as $G\left(\frac{\eta}{\gamma\left(y-R_{I}\right)}\right)$. 


\section{Monopoly Lender's Problem}

Before introducing competition, we study the case when the incumbent lender (denoted I) is a monopolist. The lender's expected profit from each loan when the bank cannot distinguish borrower types is:

$$
E \pi_{I}=E\left[\theta \mid \theta>\frac{\eta}{\gamma\left(y-R_{I}\right)}\right] R_{I}-d_{I}
$$

Revenue depends on the expected probability of loan repayment, which is equal to the likelihood of project success, and the interest rate. The cost of making the loan is the opportunity cost of intermediated funds, or the deposit interest rate $\left(\mathrm{d}_{\mathrm{I}}\right)$.

Consider a closed financial system with a fixed amount of deposits, i.e., no interbank market. The rationing equilibrium in the monopoly case when the bank cannot distinguish borrower types is the following:

$$
\gamma^{m} G\left(\frac{\eta}{\gamma^{m}\left(y-R_{I}\right)}\right)=D
$$

Here, D, the amount of deposits, is taken as exogenous and is normalized by population. The probability of getting a loan in equilibrium is the probability for which the number of willing borrowers times the probability just equals the percent of the population that can be funded. To avoid the degenerate case in which the lender does not lend at all, we assume that the interest rate is set at a level at which lending is profitable. Since the lender cannot distinguish among borrowers, she must be willing to lend to all borrowers and can do no better than allocate loans randomly. Denoting the solution to the monopolist's problem with superscript $\mathrm{m}$, the probability of getting a loan approved $\left(\gamma^{\mathrm{m}}\right)$ and the lowest type in the borrowing pool $\left(\theta^{\mathrm{m}}\right)$ are endogenously determined by (3), where 


$$
\theta^{m}=\frac{\eta}{\gamma^{m}\left(y-R_{I}\right)}
$$

Effort by the Lender. Next, we consider how the lender responds to the opportunity to exert costly effort in order to gain information about borrower types. ${ }^{0} \mathrm{We}$ assume that effort is a discrete choice ( $\mathrm{e}=0$ or 1 ) that incurs a variable cost per loan $\left(\mathrm{c}_{\mathrm{I}}\right)$, the lender must commit to screening all borrowers or none at all,, 0 and borrowers can observe this commitment. ${ }^{\square}$ If the cost of effort had a high fixed component, competition would increase the per-loan cost of effort by reducing the deposit base of incumbent banks, and there would be an immediate economies of scale rationale for regulating competition.

If the lender chooses to exert effort in screening loans, she learns the borrower's type and is able to allocate loans based on that information. Her expected profit for each loan is:

$$
E \pi_{I}=E\left[\theta \mid \theta>\theta^{s}\right] R_{I}-d_{I}-c_{I}
$$

where $\theta^{\mathrm{s}}$ is the cutoff quality that brings loan demand and loan supply into equilibrium assuming that the deposit constraint is binding, or $G\left(\theta^{s}\right)=D$. Because borrowers can anticipate perfectly whether they will be successful in getting a loan given a screening commitment by the lender, they only apply when they know they will be accepted, so that rationing is unnecessary. The bank's effort incentive depends on the change in the quality of loans, the interest rate, and the cost of effort.

\section{Competition Under Credit Rationing}

We consider a duopoly game in which the incumbent rations credit at a regulated, below-market interest rate, but can exert effort in screening or enforcing loan repayment. The entrant is free to choose its own interest rate and also can exert effort. All effort is observable to borrowers. 
We assume that deposit competition and loan competition are separable. ${ }^{12}$ Thus, deposit competition occurs in a first stage and the amount of deposit business that the entrant can steal or generate is independent of lending decisions. In general, RCFs offer higher returns but offer less security to potential depositors, who must weigh both factors in deciding where to place their funds. Anticipating the empirical results below, we assume that the entrant steals deposits but does not increase total deposits, so that $\mathrm{D}$ is the same as in the monopoly case.

$$
D=D_{E}+D_{I}=\alpha D+(1-\alpha) D
$$

$\mathrm{D}_{\mathrm{E}}$ is deposits of the entrant and $\mathrm{D}_{\mathrm{I}}$ is deposits of the incumbent. The share of total deposits held by the entrant is $\alpha$.

There are 4 possible effort outcomes: neither incumbent nor entrant exert effort $\left(e_{I}=0\right.$ and $\left.e_{E}=0\right)$, only the incumbent exerts effort $\left(e_{I}=1, e_{E}=0\right)$, only the entrant exerts effort $\left(\mathrm{e}_{\mathrm{I}}=0, \mathrm{e}_{\mathrm{E}}=1\right)$, and both the incumbent and the entrant exert effort $\left(\mathrm{e}_{\mathrm{l}}=1, \mathrm{e}_{\mathrm{E}}=1\right)$. We describe the outcomes (including the interest rate set by the entrant) for these four cases and then describe the Nash equilibria of the game. The payoffs to the entrant and the incumbent in each case are summarized in Figure 1.

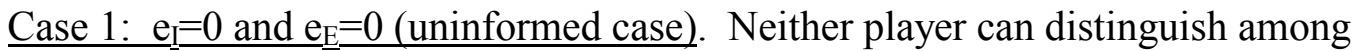
types, so that each must randomly select among borrowers that apply for loans. For borrowers, the relative profitability of applying to different banks depends on differences in the interest rate and the probability of getting a loan, but not the borrower's own type. In equilibrium, if borrowing occurs from both institutions, all potential borrowers must be indifferent between the two. This suggests the following equilibrium condition:

$$
\gamma_{E}\left(y-R_{E}\right)=\gamma_{I}\left(y-R_{I}\right)
$$

Consider a starting point in which the entrant charges the same regulated interest rate as the incumbent, and both ration at the same rate $\left(\gamma_{\mathrm{E}}=\gamma_{\mathrm{I}}\right)$. From the entrant's perspective, if there are more applicants than available funds $\left(\gamma_{\mathrm{E}}<1\right)$, it is always 
profitable to raise his interest rate (profits increase both because of the higher interest rate and because the pool of borrowers improves). Thus, the entrant's interest rate will always be greater than that of the incumbent. As the entrant raises his interest rate, potential borrowers rush to the incumbent until the point that increased rationing by the incumbent and decreased rationing by the entrant (lower $\gamma_{\mathrm{I}}$ and higher $\gamma_{\mathrm{E}}$ ) restores the equilibrium condition (7) and all borrowers are once again indifferent between the two banks. Because of the incentive just described, the entrant will always raise $R_{E}$ until $\gamma_{\mathrm{E}}=1$, so that there is no rationing by the entrant. The lower $\gamma_{\mathrm{I}}$ also means that the poorest types that borrowed under monopoly are no longer willing to apply for loans. Thus, the borrowing pool improves for the incumbent even though the share of applicants getting loans falls.

Once $\gamma_{\mathrm{E}}=1$, if the entrant continues to raise $\mathrm{R}_{\mathrm{E}}$, loan demand will fall below the amount of deposits, reducing profits. However, if the entrant anticipates that borrowers refused by the incumbent may subsequently apply for a loan from the entrant, he may continue to raise the $\mathrm{R}_{\mathrm{E}}$ and still eventually have sufficient loan demand to exhaust all of his deposits. In general, the entrant will maximize profits by setting $R_{E}$ high enough to attract only borrowers of type $\theta^{\mathrm{s}}$ or above, or so that:

$$
\theta^{s}=\frac{\eta}{y-R_{E}^{s}}
$$

Recall that $\theta^{\mathrm{s}}$ is the cutoff level for which loan demand and supply are equal when there is a single lender exerting effort to screen borrowers. Potential borrowers may rush to the incumbent, but only up to the point that the expected return of doing so is higher. This expected return decreases as rationing increases until it is exactly equal to applying to the entrant (equation 7). In equilibrium, then, only borrowers of type $\theta^{\mathrm{s}}$ apply for loans, whether from the incumbent or the entrant. All borrowers refused by the incumbent then apply to the entrant and are given a loan, and total borrowing just exhausts available deposits. ${ }^{\square}$ The result is that both the entrant and incumbent lend to all borrowers with

\footnotetext{
${ }^{1}$ It is possible that the higher entrant interest rate drives all borrowers to the incumbent and that even with rationing, the returns to borrowing from the incumbent is greater than borrowing from the entrant. This means that types below $\theta^{\mathrm{s}}$ will apply for loans from the incumbent, so that a greater number of borrowers with types above $\theta^{\mathrm{s}}$ will not obtain loans and so apply to the entrant. In this case, the entrant can raise its
} 
type $\theta^{\mathrm{s}}$ or above. Note that without exerting effort, the borrowing pool of the incumbent improves in quality, and is the same as in the monopoly case with effort.

Case 2: $\mathrm{e}_{\mathrm{I}}=1$ and $\mathrm{e}_{\mathrm{E}}=0$. If the incumbent can efficiently ration available credit to the best customers, she can increase the profitability of her loan portfolio. She can also ensure that the best customers have a one hundred percent probability of getting a loan if they apply. The entrant, on the other hand, cannot guarantee high types that they will receive loans if they apply, because at the regulated interest rate there is excess demand for loans and he cannot distinguish the quality of borrowers. Thus, the entrant will be left with a secondary pool of borrowers not served by the incumbent. When the incumbent gets all of the best borrowers, the lowest type that borrows from the incumbent is described by the condition $G\left(\theta_{I}^{b}\right)=(1-\alpha) D$. Here, $\theta_{\mathrm{I}}^{\mathrm{b}}$ will be higher than $\theta^{\mathrm{s}}$, the lowest type when the monopolist exerts effort, because with fewer deposits the incumbent can be more selective.

The entrant can use the interest rate to select the best types among the remaining applicants. He will raise the interest rate to the level at which loan demand equals his supply of deposits. Thus, the lowest and highest types that borrow from the entrant are $\theta^{\mathrm{s}}$ and $\theta_{\mathrm{I}}^{\mathrm{b}}$. The lower bound $\theta^{\mathrm{s}}$ is the same as in the monopoly case with effort.

Case 3: $\mathrm{e}_{\mathrm{I}}=0$ and $\mathrm{e}_{\mathrm{E}}=1$. In this case the entrant has two possible strategies. Case $3 \mathrm{~A}$ is that the entrant sets the interest rate as in Case 1 to be as high as possible and still attract enough borrowers, including incumbent refusals, to exhaust all of his deposits. The borrowing pool quality is identical for entrant and incumbent, and effort plays little role. A second strategy, $3 \mathrm{~B}$, is for the entrant to use its knowledge of borrower types to guarantee access to loans to the best borrowers at a rate that makes the entrant a more attractive lender than the incumbent. To accomplish this, the interest rate must be set at a rate just below $R_{E}^{L}$, the rate at which (7) holds and initial loan demand, not including incumbent refusals, exhausts available deposits of the entrant. In case 1, this was described as the (lowest) rate at which $\gamma_{\mathrm{E}}=1$ just holds. Formally, $R_{E}^{L}$ is the interest rate consistent with the rationing rate $\gamma^{\mathrm{L}}$ determined by the condition: 


$$
G\left(\frac{\eta}{\gamma^{L}\left(y-R_{I}\right)}\right)=\alpha D+\frac{(1-\alpha) D}{\gamma^{L}} .
$$

$R_{E}^{L}$ solves the equation $\left(y-R_{E}\right)=\gamma^{L}\left(y-R_{I}\right)$. There is no rationing by the entrant and borrowers are indifferent between the two lenders. Now the entrant can capture all of the best buyers by lowering the interest rate just slightly (asymptotically the same). Without effort, this would attract more borrowers and lead to rationing by the entrant until borrowers were once again indifferent between the two lenders. However, with effort the entrant can guarantee loan access to the best types and thus be more attractive than the incumbent. In summary, the entrant's strategy $3 \mathrm{~A}$ involves a higher interest rate and comparable borrowing pools for the entrant and incumbent while his strategy $3 \mathrm{~B}$ involves a lower interest rate and capture of the best borrowers.

Case 4: $\mathrm{e}_{\mathrm{I}}=1$ and $\mathrm{e}_{\mathrm{E}}=1$. With perfect information, all decisions are anticipated, so that those expecting rejection do not apply--they are "discouraged" borrowers. With both sides exerting effort, the entrant again can pursue one of two strategies. First, he can steal all of the best customers by setting the interest rate slightly below that of the incumbent (strategy 4A, Figure 1). Second, he can let the incumbent have the best customers, and lend to the secondary pool at a higher interest rate, for which the payoff is the same as in case 2 except for an additional cost of effort (Figure 1). As in case 3, the optimal choice of strategy depends on whether it is more profitable to lend to better customers at a lower rate or to worse customers at a higher rate.

Equilibrium Strategies. We summarize entrant and incumbent payoffs for the four cases in a two-by-two payoff matrix (Figure 1). To avoid degenerate cases in which costs of effort are prohibitively high, we make the following assumptions:

$$
\begin{aligned}
& \text { A1: } C_{I}<R_{I}\left\{E\left[\theta \mid \theta_{I}^{b} \leq \theta\right]-E\left[\theta \mid \theta^{s} \leq \theta\right]\right\} \\
& \text { A2: If } R_{E}^{L} E\left[\theta \mid \theta_{E}^{b} \leq \theta\right]>R_{E}^{s} E\left[\theta \mid \theta^{s} \leq \theta\right],
\end{aligned}
$$




$$
\begin{aligned}
& \text { then } C_{E}<R_{E}^{L} E\left[\theta \mid \theta_{E}^{b} \leq \theta\right]-R_{E}^{s} E\left[\theta \mid \theta^{s} \leq \theta\right] . \\
& \text { A3: If } R_{I} E\left[\theta \mid \theta_{E}^{b} \leq \theta\right]>R_{E}^{s} E\left[\theta \mid \theta^{s} \leq \theta \leq \theta_{I}^{B}\right], \\
& \text { then } C_{E}<R_{I} E\left[\theta \mid \theta_{E}^{b} \leq \theta\right]-R_{E}^{s} E\left[\theta \mid \theta^{s} \leq \theta \leq \theta_{I}^{B}\right] .
\end{aligned}
$$

Assumption A1 states that the cost of effort is sufficiently low that, in competition, the incumbent is willing to exert effort if doing so leads to full capture of the best borrowers. Assumptions A3 and A4 state that if the entrant's expected revenues are higher when pursuing high quality borrowers at a lower interest rate (strategies $3 \mathrm{~B}$ and $4 \mathrm{~B}$ ) rather than lower quality borrowers at a higher interest rate (strategies $3 \mathrm{~A}$ and $4 \mathrm{~A}$ ), the costs of effort are sufficiently low that pursuing high quality borrowers is profit-maximizing.

The outcome of the effort game described in Figure 1 depends on the optimal choices by the entrant of $3 \mathrm{~A}$ versus $3 \mathrm{~B}$, and $4 \mathrm{~A}$ versus $4 \mathrm{~B}$. The important equilibrium outcomes of the game are summarized in the following proposition:

\section{Proposition 1: Equilibrium Outcomes}

1) Given $A 1$, if the entrant prefers $4 \mathrm{~A}$ to $4 \mathrm{~B}$, the outcome is case 2 .

2) Given, $\mathrm{A} 1, \mathrm{~A} 2$, and $\mathrm{A} 3$, if the entrant prefers $4 \mathrm{~B}$ to $4 \mathrm{~A}$ and $3 \mathrm{~B}$ to $3 \mathrm{~A}$, the outcome is case $3 \mathrm{~B}$.

Proof: Follows directly from payoffs in Figure 1.

Although it is possible for the entrant to prefer $4 \mathrm{~B}$ to $4 \mathrm{~A}$ and $3 \mathrm{~A}$ to $3 \mathrm{~B}$, such an outcome is unlikely because 4B and 3B both are more attractive when the expected return of lending only to the best borrowers is significantly higher than lending to the secondary pool.

Thus, the two most likely outcomes under competition are that the incumbent or entrant exerts effort to capture the best borrowers while the competitor does not exert effort. While there is likely to be regional and temporal variation in whether the entrant is willing to compete for the best borrowers, given China's institutional environment, we expect that in many cases the entrant will pursue the secondary pool and case 2 will 
obtain. Given that few RCCs have been able to lend profitably at low regulated interest rates, and that the cost of funds of RCFs is typically higher than that of RCCs, it seems unlikely that many RCFs would be able to lend profitably at the low regulated rates. The attraction of lending to the secondary pool at a higher rate should also be greater in richer areas where the number of credit-worthy borrowers is likely to be greater.

An important feature of the competitive outcomes illustrated in Figure 1, is that in all cases, the lowest type of borrower obtaining a loan from either institution is $\theta^{\mathrm{s}}$. This suggests that competition improves aggregate financial performance, even when one or both lenders are not exerting effort. Efficiency gains can occur without effort because of the entrant's ability to select better borrowers through self-selection at higher interest rates. This is in contrast to the monopoly case (see second table in Figure 1) in which efficient lending occurs only if the lender exerts effort. For incumbents, the threshold borrower quality necessary to obtain loans under competition is always greater than or equal to that under monopoly, although whether this leads to higher per-loan expected profits is ambiguous because of the possibility that the entrant steals the best borrowers.

\section{Competition and Reform}

We are interested in whether competition increases effort (or reform) incentives for the incumbent. To do so, we compare the difference between incumbent payoffs with and without effort under competition and under monopoly. We focus on case 2 , the outcome from part 1) of Proposition 1. 目 If the incumbent exerts effort, case 2 obtains. If she does not exert effort, the outcome is case 1 if the entrant prefers $3 \mathrm{~A}$ over $3 \mathrm{~B}$, or case $3 \mathrm{~B}$ if the entrant prefers $3 \mathrm{~B}$ over $3 \mathrm{~A}$ (applying $\mathrm{A} 2$ ). We can then write the gain to effort in these two cases as follows:

$$
\begin{gathered}
\pi_{2}-\pi_{1}=R_{I}\left\{E\left[\theta \mid \theta_{I}^{b} \leq \theta\right]-E\left[\theta \mid \theta^{s} \leq \theta\right]\right\}-c_{I} \\
\pi_{2}-\pi_{3 B}=R_{I}\left\{E\left[\theta \mid \theta_{I}^{b} \leq \theta\right]-E\left[\theta \mid \theta^{s} \leq \theta \leq \theta_{E}^{b}\right]\right\}-c_{I}
\end{gathered}
$$

\footnotetext{
${ }^{2}$ If the entrant prefers $4 \mathrm{~B}$ to $4 \mathrm{~A}$ and $3 \mathrm{~A}$ to $3 \mathrm{~B}$, there are no pure strategy Nash equilibria.

${ }^{3}$ If the entrant prefers $4 \mathrm{~B}$ to $4 \mathrm{~A}$, as in part 2) of Proposition 1, the effort incentive of the incumbent is unambiguously less under competition because the incumbent gets only the secondary pool even when she exerts effort.
} 
We compare these to the return to effort under monopoly:

$$
\pi_{M}(e=1)-\pi_{M}(e-0)=R_{I}\left\{E\left[\theta \mid \theta^{s} \leq \theta\right]-E\left[\theta \mid \theta^{m} \leq \theta\right]\right\}-c_{I}
$$

The difference in the return to effort under competition versus monopoly depends on the difference in the expected increase in borrower quality from exerting effort in the two cases. For example, comparing (10) and (12), the effort incentive under competition is greater if the following expression is greater than zero:

$$
\left(E\left[\theta \mid \theta_{I}^{b} \leq \theta\right]-E\left[\theta \mid \theta^{s} \leq \theta\right]\right)-\left(E\left[\theta \mid \theta^{s} \leq \theta\right]-E\left[\theta \mid \theta^{m} \leq \theta\right)>0\right.
$$

Although in general whether (13) holds is indeterminate, simplifying this expression for the case of a uniform distribution, we find that (13) is true if the following condition holds:

$$
\alpha+1-\frac{1}{\gamma^{m}}>0
$$

It turns out that comparing (11) to (12) yields an identical expression except that the $\alpha$ is multiplied by two. The key to these simplifications is recognizing that under a uniform distribution, $\gamma^{m}\left(1-\theta^{m}\right)=\left(1-\theta^{s}\right),\left(1-\theta_{E}^{b}\right)=\alpha\left(1-\theta^{s}\right)$, and $\left(1-\theta_{I}^{b}\right)=(1-\alpha)\left(1-\theta^{s}\right)$. Whether (14) holds is also indeterminate, but we can see clearly that the effect of competition on the incumbent's effort incentive depends positively on the entrant's market share and negatively on the extent of credit rationing when there is a monopolist lender, which increases the effort incentive under monopoly.

\section{Other Considerations}

Fund Balance. Thus far, we have assumed throughout that both the incumbent and entrant always lend out all available funds (the deposit constraint is binding). In theory, banks also can lend amounts less than available deposits if there are an 
insufficient number of profitable projects identified when projects are screened. Thus, if incumbent lending falls under competition, it may indicate greater lending effort. ${ }^{.3}$ None of the models main qualitative results change.

Heterogeneous Cost of Effort. As noted earlier, our model does not assume that the cost of effort is the same for RCCs and RCFs. Differences are possible, if for example, the quality of staff differs. The poor management ability of RCC staff is frequently cited in the Chinese literature (e.g., He, Huang, and Liu, 1997, Zhou and Chen, 1998). However, RCC staff may have greater experience than newer RCF staff. RCFs, by lending mainly to members, may also have information advantages associated with mutual monitoring incentives in true cooperatives. In addition, it is possible that abilities differ not just by institution but by loan type within institutions. For example, RCFs may have better information technology for household lending but RCCs may have advantages in monitoring enterprises. In this way, competition may affect the loan composition of both incumbent and entrant.

Policy Lending. Non-profit considerations may affect lending decisions of either incumbent or entrant, affecting loan composition, repayment rates, and profits. For example, loan officers may be pressured to finance local industrial projects being promoted by local leaders interested in their revenue-generating potential, loan officers may favor relatives or be otherwise corrupt, and RCFs may give priority to share-holders, i.e., depositors, or to agricultural projects, since they are under the administrative supervision of the Ministry of Agriculture.

Reputational Lending. Several papers have shown that competition can undermine the ability of banks to engage in reputational lending, since banks cannot ensure claims to future rents when deciding to enter into committed lending relationships with promising firms (Peterson and Rajan, 1995; Besanko and Thakor, 1993). Dinc (2000), however, argues that when the number of banks is small, competition can enhance reputational lending because monopolists can extract so much of the rent from borrowers that committed lending is not optimal. The intuition of these models should extend to competition under credit rationing. Dinc's result suggests that reputational effects in the duopoly case will not reverse the positive effects of competition on 
incumbent effort, but results from other models raise the possibility that effects on reputational lending could alter the predicted effects on bank profits and social welfare.

\section{Competition in China's Rural Financial Markets}

Background

In China, the Rural Credit Cooperatives (RCCs) for many years have been the main financial institutions taking deposits and providing loans to rural households and enterprises. RCCs, despite their name, receive supervision mainly from state banks and lack governance or shareholding by members. ${ }^{4}$ According to a national village survey in 1996, about two thirds of rural household deposits are held in RCCs, the only financial

institution with a branch network extending down to the village level. ${ }^{15}$ RCCs are also by far the most important source of formal credit for rural households (Park, Brandt, and Giles, 1997). In recent years, the Agricultural Bank of China (ABC) and to a much lesser extent other state banks, have also lent to rural enterprises and households. ABC branches, however, do not reach many townships and they lend significant amounts to state agricultural marketing companies. As a result, RCCs in many areas have enjoyed a near monopoly over deposits and lending. 16

RCC interest rates, interbank lending (and other fund uses), reserve requirements, and the range of financial instruments available to borrowers and lenders remain highly regulated. China's official interest rates are well below market-clearing levels, leading to credit rationing. Shortage of credit is exacerbated by the significant share of financial resources targeted to loss-making state-owned enterprises (Lardy 1998). Limited opportunities for inter-bank lending make lending volume of each branch highly dependent on the amount of RCC deposits (Park and Sehrt, 2001; Shen, 2000).

Beginning in the late 1980s, a new and dynamic financial institution emerged in some rural areas. Rural Cooperative Foundations (nongcun hezuo jijinhui, or RCFs) are quasi-state organizations under the administrative supervision of the Ministry of Agriculture, often organized with the direct support or supervision of local township government leaders. Lacking legal status as financial institutions, RCFs in many areas were able to offer effective interest rates on loans and deposits that exceeded official 
rates. They received endorsement by China's State Council in 1986 and grew rapidly thereafter, with funds reaching about 100 billion yuan by year-end 1996 compared to 880 billion yuan in RCC deposits (Cheng, Findlay, and Watson, 1997). Our survey described below found that in 1995 the average percentage of rural deposits (sum of RCCs and RCF deposits) in RCFs averaged 7 percent for all villages, and 18 percent for villages with RCFs. Forty-one percent of surveyed townships have RCFs, close to the 38 percent national figure reported by $\mathrm{Du}$ (1998) for 1996.

The first rural credit foundation in China was established in the mid-1980s in Sichuan Province by an agricultural official working at the township agricultural economic management station as a way to better manage village collective funds. ${ }^{-1}$ The stated goal of RCFs in Sichuan was to meet the demand for funds by agricultural households and to support the three nong's - nongcun (village), nongye (agriculture), and especially nonghu (rural households). Because officially they were not financial institutions, RCFs could not take deposits or make loans, but instead collected shares and allowed borrowing, often only to members. Most profits were distributed to shareholders as dividends, which combined with interest payments made the realized return on shares higher than on bank deposits. RCFs expanded rapidly in the regions where they were introduced because of the strong support of local communities. Township officials preferred the greater independence of RCFs as a source of funds for local development when compared to RCCs that were subject to credit plans and other regulations. Rural households were attracted by the higher returns and greater access to funds.

Both RCCs and RCFs relied on household deposits as their main source of funds (71 and 62 percent of funds on average in 1995, Table 1). The importance of collective funds was much greater for RCFs ( 25 percent compared to 7 percent for RCCs), who unlike RCCs also drew funds from government and other organizations. This pattern suggests that collectives had a larger relative stake in the operations of RCFs. On the uses side, RCCs lent a much greater share of loans to township and village enterprises (TVEs) than RCFs (29 percent compared to 18 percent) as well as to other commercial borrowers (Table 1). TVEs are Chinese rural enterprises, most of which are owned by community governments. Most lending by RCFs goes to households (55 percent), 
slightly higher than RCCs overall (52 percent), and much higher than RCCs in the same townships (35 percent).

Despite and perhaps because of their success, regulation of RCFs became a potent political question in China. Because they competed directly with RCCs, they were viewed as competitors that drew away funds by taking advantage of unequal treatmentless strictly regulated interest rates and tax exemption (because they lacked status as formal financial institutions). The State Council in 1998 sided with banks in recommending that RCFs be incorporated into the RCC system or be dissolved. Voicing opposition were many local government leaders as well as the Ministry of Agriculture, who preferred greater local control and more support for rural household activities. Implementation of this proposal was the subject of intense debate within China, culminating in the dissolution of RCFs in 1999 (Holz, 2001). Some of the key empirical issues underpinning this controversy are the following. To what extent do RCFs steal deposits from RCCs and to what extent do they generate new deposits? Do RCFs provide competitive pressure leading to improved RCC effort and performance, or do they steal good customers and undermine RCC profitability? Do RCFs better meet the needs of rural households and deepen financial intermediation in rural areas? We hope to shed light on all of these questions.

We analyze a unique data set from surveys of rural financial institutions, villages, and townships in 12 Chinese provinces collected by the authors in 1996 and 1997.18 RCCs and RCFs (if they existed) were surveyed in over 100 townships. The survey collected information on the sources and uses of funds, profits and income, estimated rates of repayment, including overdue loans, loan conditions, staff, and enforcement measures to collect overdue loans. The village and township surveys provide data on basic economic variables, and describe local household savings and lending behavior, both formal and informal. Institutions differed in how completely they were able and willing to fill out questionnaires, leading to differences in the number of valid observations for the different estimations reported below. To our knowledge, the survey is the only survey of a national sample of rural financial institutions in China or other developing countries. 


\section{Effects of Competition}

Our main empirical concern is to test whether competition affects the effort and lending decisions of the incumbent. An estimable equation for measuring such effects is the following:

$$
Y_{t}=\alpha R C F_{t}+\beta X_{t}+\varepsilon_{t}
$$

Here, $\mathrm{Y}_{\mathrm{t}}$ is a vector of outcome variables, including deposit growth, loan composition, loan repayment, and bank effort indicators; $\mathrm{RCF}_{\mathrm{t}}$ is a dummy variable for $\mathrm{RCF}$ presence, which can be considered a "treatment" variable; $\mathrm{X}_{\mathrm{t}}$ is a vector of township economic indicators (income per capita, industrial share of income); and $\varepsilon_{\mathrm{t}}$ includes unobserved township and bank characteristics, measurement error, and other sources of random error. We also consider a second measure of RCF presence--the share of total deposits held in RCFs (RCFDEPS), which represents RCF's market share, which the theory finds directly

effects the effort incentives associated with competition.

Nonrandom establishment of RCFs creates an obvious endogeneity problem in estimating the effect of competition on RCC performance. However, if we can identify exogenous (or predetermined) variables that predict entry but are unlikely to be correlated with the unexplained portion of current outcomes $\left(\varepsilon_{t}\right)$, these variables can serve as instruments for the treatment variable. This leads us to an investigation of the factors that determine RCF entry.

\section{RCF Establishment}

Table 2 describes characteristics of townships in which RCFs did and did not locate. The data is for 1988 , before any RCFs were established. On average, RCFs located in townships with higher incomes per capita (1146 to 893) and greater industrialization. The industrial share of income in townships with RCFs was 33 percent, in other townships 27 percent. There appears to be little difference in the population or relative importance of informal lending. 
The timing of RCF establishment varies considerably by province. RCFs have the longest history and are most common in Sichuan, where over 80 percent of townships had RCFs by 1996.20 The percentage of surveyed townships reporting RCFs was 41 percent, with considerable variation across provinces. ${ }^{2}$ Most of the RCFs in Sichuan, Liaoning and Hebei were established in the late 1980s and very early 1990s. In Jiangxi and Zhejiang (a poor and rich province), RCFs were not established until 1994-1995. These differences reflect heterogeneity among provincial governments in awareness, regulatory attitude, and promotion of RCFs. We assume that townships in a province are not at risk of having an RCF until the year in which the first RCF is observed. We test which environmental factors best predict RCF establishment by estimating a proportional hazard model. To account for provincial heterogeneity, the baseline hazard is allowed to vary by province.

The hazard rate is estimated using spell data defined as the period of time in which townships do not have RCFs, counting from the beginning of the year in which RCFs are first observed in the province. Because many townships still had no RCFs by the 1996 survey date, these observations are treated as censored. We can account for time-varying covariates by dividing each spell observation into annual records, where annual observations for the years before RCF establishment are treated as censored.

Ideal exogenous environmental variables affecting RCF establishment would be township characteristics in the year preceding all years in which townships were at risk of RCF establishment. However, the only historical township data collected in the survey was for 1988. Using these data has two drawbacks. First, the data for 1988 is incomplete since many interviewed townships had incomplete records. Second, the data is for a year which often predates the establishment of RCFs by many years, and so is a noisy measure of the economic environment at the time when township leaders were considering whether to establish RCFs. To avoid these problems, we use annual county-level data from the Ministry of Agriculture, reconciling ourselves to the loss of township variation. We posit that the likelihood of RCF establishment in period $t$ is a function of four economic variables in the previous year (t-1): CINCPC--per capita income, CINCG, 
growth rate of income per capita, $\mathrm{CINDSH}$ - industrial share of income, and $\mathrm{CPOP}-$ county population.

Estimation results are presented in Table 3. Only the coefficient for industrial share of income is statistically significant, while that on population is nearly so. RCFs are more likely to locate in industrial, highly populated counties.

\section{Instrumenting for Competition}

The significant relationship between industrial development and establishment of RCFs suggests that lagged industrial share of output may be an appropriate instrument for the existence and size of RCFs. Within a province, the appropriate exogenous instrument is industrial share of output in the year before townships in the province were first put at risk of RCF establishment (initial characteristics). However, because both the duration of time at risk and the baseline hazard vary by province, the effect of an initial characteristic on the likelihood of observing an RCF in 1995 will differ by province. For this reason, our chosen set of instruments are initial industrial share of income (IND) interacted with provincial dummy variables for provinces that have RCFs.

The attraction of this choice is that it exploits the exogenous variation in provincial policy differences to help identify the effects of RCF presence on RCC performance. It is also plausibly uncorrelated with RCC performance. First, it is a lagged value of industrial share of output and all specifications control for current values of IND. Second, provincial differences in the effect of initial IND on RCF location are unlikely to correlate with provincial differences in the effect of initial IND on RCC performance, because of the quasi-random nature of initial introduction of RCFs into different provinces. For example initial industrial share in Sichuan is for the year 1987, which probably has a big effect on the probability of an RCF existing in 1995 (because the propensity and time for establishing RCFs in Sichuan is high), but likely has a small effect on 1995 performance (presuming there is a lagged effect), because it is so long ago. Initial industrial share in Zhejiang, from 1993, will have a smaller effect on the likelihood of there being an RCF and a larger effect on current performance. In this case the errors 
in the outcome equation are unlikely to be correlated with the predicted probabilities of RCF existence.

Our IV estimator implicitly treats the probability of treatment as a linear function of the instruments. The attraction of this approach is that it imposes no distributional assumptions for consistency (Heckman and Robb, 1985) and allows us to easily implement recommended procedures for dealing with weak instruments. Many of our first-stage regressions of the RCF variables on the instruments and exogenous regressors find that the instruments are jointly significant but have relatively low F-statistics, which can cause bias and understate standard errors using conventional IV estimators (Bound et al, 1994). ${ }_{2}$ However, the limited information maximum likelihood (LIML) instrumental variables estimator remains consistent even with weak instruments (Staiger and

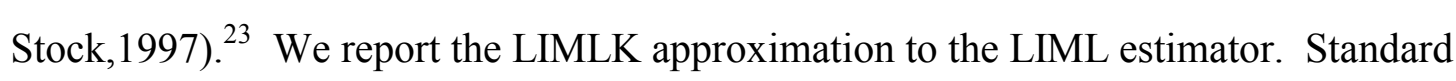
errors are calculated using the approximation by Bekker (1994) for large instrument sets, which has been shown to have relatively good coverage rates for the weak instrument case (Hahn and Inoue, 1999). ${ }^{24}$ As a second test of whether the coefficients on the RCF variables are nonzero, we calculate the Anderson-Rubin statistic recommended by Staiger and Stock (1997), although this test is invalid if the instruments fail the overidentification tests and has less power with large instrument sets. ${ }^{25} \mathrm{We}$ also report results for the Basmann over-identification test and the Durban exogeneity test, which Staiger and Stock (1997) find to be most appropriate for small F based on Monte Carlo experiments. These tests are standard ones for testing the appropriateness and need for the chosen instrumental variables. To sum up, for each LIMLK-IV estimate, we report the first-stage F-statistic and p-value, and the p-values for the Basmann overidentification test, Durbin exogeneity test, and AR test (for the RCF coefficient). For comparison, we also report OLS coefficient estimates for the RCF variables. We present LIMLK-IV estimation results on the effect of RCF competition on different aspects of RCC performance - deposit growth, lending volume, loan composition, loan repayment, and screening and enforcement effort.

\section{Competition and RCC Performance}




\section{Deposit Growth}

One of the main policy concerns related to the emergence of RCFs is the extent to which they are diverting deposits from RCCs. At the same time, the higher returns offered by RCFs could be mobilizing new deposits, promoting better overall intermediation of financial resources. Although RCFs on average account for only 18 percent of total deposits in townships where they exist compared to 82 percent for RCCs, their deposits have grown rapidly, with a median growth rate of 46 percent in 1995 (Table 4). This compares to 11 percent deposit growth for RCCs. RCC deposit growth is somewhat less in townships with RCFs (9 percent versus 13 percent in other townships), but there is considerable variation across townships.

We regress change in RCC and total deposits per capita (RDCHPC and TDCHPC) from 1994 to 1995 on the following variables: initial RCC or total deposits per capita $\left(\mathrm{RDEPPC}_{\mathrm{t}-1}\right.$ or $\left.\mathrm{TDEPPC}_{\mathrm{t}-1}\right)$, township income per capita (INCPC); industrial share of township output value (INDSH), a dummy for the year surveyed (YEAR), and a set of provincial dummies. This specification allows deposit increases to be proportional both to initial deposits (which should help pick up the effect of unobservables on the level of deposits) and to income (measuring the marginal propensity to save). Measures of RCF presence can be entered independently or interacted with initial deposits or income per capita, depending on whether we believe the effect of competition is proportional to these variables. We try all three possibilities and find significant effects for the interacted specifications only, especially with initial deposits. ${ }^{26}$ In Table 5, we report the estimation results when RCF presence is interacted with initial deposits.

The presence of an RCF (coefficient of -0.75) almost fully negates the positive and large growth in RCC deposits in areas without RCFs (0.79). Also, a one percent increase in RCF deposit share causes a reduction of 2.92 percent in the deposit growth rate. ${ }^{27}$ The effects on deposits are significantly larger for the IV estimates, which is expected if RCFs tend to locate in areas with faster deposit growth. The point estimates for RCF presence in the total deposit change equations are slightly negative but relatively imprecise. All specifications have significant but weak instruments, pass the Basmann overidentification test at the 10 percent significance level, and fail the Durbin exogeneity 
test. The AR statistics are significant for RCC deposit growth but not total deposit growth. Overall, there is no evidence that RCFs increase the overall level of deposits. RCFs thus appear to steal but not create business.

\section{$\underline{\text { Loan Composition }}$}

With fewer deposits and a new competitor providing loans to local households and enterprises, do RCCs adjust their loan portfolio? A key issue is whether a separation occurs in the customers of the two institutions based on borrower characteristics. One of our most robust findings is that in townships with RCFs, a much higher percentage of

RCC lending goes to TVEs and a much lower percentage goes to households. 2.8

We estimate equations for TVE and household loan shares, both in levels and in differences (using 1988 data). The differenced regressions better account for timeinvariant heterogeneity but ignore the spatial variation. To control for some of the timeinvariant heterogeneity in the level regressions, we include 1988 loan shares. The level regressions find that the presence of an RCF increases the TVE loan share by 31 percent and reduces the household loan share by 31 percent, or 1.29 and 1.22 percent for each percent increase in RCF deposit share (Table 6). The differenced regressions suggest smaller but still large effects: a 16 percent increase in TVE loan share and a 22 percent reduction in household share, or 0.75 and 0.64 percent changes for each percent increase in RCF deposit share (Table 6).

While RCCs in townships with RCFs concentrate lending on TVEs (40 percent on average), RCFs themselves lend mostly to households (55 percent on average, Table 1). Next, we investigate the effect of RCFs on the total loan portfolio of RCCs and RCFs combined. We find that RCF presence increases the combined TVE loan share by 17 (4) percent and reduces combined household lending share by 26 (19) percent based on level (differenced) regressions (Table 7). However, the TVE differenced regression and all of the regressions with RCC deposit share produce statistically insignificant results, even though the signs are consistent (positive for TVE loans, negative for household loans). The AR statistics are significant only for the household differenced regressions. 
Thus, despite the validity of rhetoric claiming that RCFs better meet the credit needs of rural households compared to RCCs, the overall effect of RCF presence is to reduce household lending, with weaker evidence that it increases TVE lending. Nonetheless, RCF presence still may better serve households if it leads to improved screening of borrower types.

\section{$\underline{\text { Loan Repayment }}$}

One way to assess whether competition improved screening of borrowers by RCCs is to test whether RCF presence improves loan repayment performance. The survey asked managers of RCCs and RCFs to report (or estimate) the percentage of household and TVE loans repaid on time in 1995, as well as the stock of overdue loans, which we normalize by total outstanding loans.

There is some evidence that competition improves RCC loan repayment. The percent of outstanding loans overdue is 0.39 in townships without RCFs and only 0.28 in townships with RCFs, with the difference statistically significant. Household and TVE

repayment rates are 10 and 3 percent higher in townships with RCFs (Table 4). Turning to the LIMLK-IV estimates (Table 8), the presence of an RCF reduces the share of overdue loans by 33 percent, or 1.44 percent for each percentage point increase in the share of RCF deposits. Three of the four competition coefficients in the repayment rate regressions are positive, the exception being the effect of RCF presence on TVE repayment. RCF presence increases household timely repayment by 21 percent, or 1.43 percent for every one percent increase in RCF deposit share. However, none of the repayment rate estimates is precisely estimated. If provincial dummy variables are excluded (in which case the Basmann test still does not reject), the coefficients on household repayment rates become statistically significant $(0.187$ with standard error 0.125 for RCF presence and $0.896(0.685)$ for RCF deposit share). This suggests that interprovincial variation in repayment rates is important. The same is true for overdue loan rates, but in that case omitting the provincial dummies leads to failure of the overidentification test. Overall, there is some evidence that RCF reduces overdue loans and increases repayment rates. This is most true for household loans, especially in the 
variation across provinces, while evidence is weakest for TVE loans. Higher household loan repayment combined with reduced household lending suggest greater screening effort under competition.

\section{$\underline{\text { Screening and Enforcement Effort }}$}

We consider three measures of screening and enforcement effort--the share of loans without guarantor or collateral requirements (NOREQ), the number of village agents employed by the RCC, normalized by the number of full-time staff (AGENTS), and the number of lawsuits initiated by the RCC in the past 3 years (LAWSUITS). Our theory suggests that anything which increases the ability of lenders to distinguish between good and bad borrowers can be considered a type of effort. Requiring guarantors or collateral of borrowers provides valuable screening information to lenders and requires additional information gathering. ${ }^{30}$ Branch managers have greater discretion to hire village agents, who are usually part-time workers, compared to regular township staff. More agents relative to staff increases decentralization, and improves local information and enforcement ability. Lawsuits, although costly, can reduce moral hazard and send signals to potential borrowers.

RCCs in townships with RCFs on average approve a much lower percentage of loans without guarantors or collateral than those in townships without RCFs (20 and 35 percent, Table 9). This is still very high compared to RCFs, which require such conditions for all but 3 percent of loans. The ratio of agents to main staff is slightly smaller in townships with RCFs ( 0.28 versus 0.34 in non-RCF townships) contrary to expectation. The number of staff, number of agents, loans per employee, wages per employee, and administrative costs per employee are all slightly greater in townships with RCFs, likely reflecting larger operations and higher opportunity costs of labor in more industrial areas. The higher costs per employee are consistent with stronger effort incentives, although the standard errors are large throughout.

The estimation results suggest that the presence of an RCF is negatively associated with NOREQ, and positively associated with AGENTS and LAWSUITS, although coefficients on competition variables are not precisely estimated in all 
specifications. An increase in RCF deposit share of one percent reduces the share of loans without requirements by 1.67 percent, and the agent to staff ratio increases by 0.164 when there is an RCF despite the possible incentive to reduce the number of employees given fewer RCC deposits and loans (Table 10). Although lawsuits may improve loan repayment by signaling greater enforcement effort, they could also reflect more repayment problems due to lower screening effort. To help control for this latter possibility, we include timely repayment rates as independent variables despite obvious endogeneity concerns. We find that high repayment rates significantly reduce lawsuits, and that controlling for repayment rates, competition variables have consistently positive coefficients. The AR statistic is significant for the RCF deposit share specification.

We also note that remaining selection bias from the endogeneity of RCF establishment to the effort level of RCCs should only strengthen the finding that RCF presence increases effort, since RCFs should be more likely to locate in areas where RCCs are exerting less effort.

\section{Summary and Discussion}

We briefly summarize the main empirical findings:

- RCFs locate in industrial, populous regions.

- RCFs steal deposits from RCCs but do not generate new business.

- Under competition, RCCs increase lending to TVEs, reduce lending to households, and reduce total lending. RCFs lend mostly to households. The combined portfolio under competition also is biased against households.

- Under competition, RCC household repayment rates are higher. There is no clear effect on TVE repayment rates.

- Under competition, RCCs exert greater screening and enforcement effort, as measured by the share of loans without guarantor or collateral requirements, the ratio of village agents to regular staff, and the number of lawsuits.

A number of these findings are consistent with the theoretical model results. The evidence on repayment rates supports the theoretical finding that screening improves 
under competition in most cases. Under competition, direct measures of incumbent bank effort increase with a higher entrant market share, also as predicted. Greater effort under competition is consistent with case 2 being the most common equilibrium outcome under competition, which we argue earlier is likely to be the case in China's rural market environment.

The finding that RCCs shift dramatically to TVE lending under competition may reflect a separation of the market in which RCCs keep the best customers (TVEs) and leave the secondary market (most household loans) to RCFs (case 2). The claim that TVEs are better customers is also supported by the result that under competition, the total loan portfolio shifts towards TVEs. ${ }^{22}$ A second explanation for separation is that RCFs have a comparative advantage in screening household loans (different ability or cost of effort). Such an advantage may come from better local information or superior monitoring incentives under cooperative institutions (Banerjee, Besley, and Guinnane, 1994). A third explanation is political-RCCs are forced to supply policy loans to TVEs and RCFs are required to favor household loans to promote agricultural development.

These different explanations yield somewhat different predictions about relative repayment rates for RCC and RCF loans in the same townships. The first suggests that all RCC loan performance should be uniformly superior, the second suggests that RCF household loans and RCC TVE loans should perform as well or better than similar loans from counterparts, and the third suggests that these same loans should perform relatively worse. In townships with RCFs for which data are available, household repayment rates for RCCs and RCFs are similar, while those for TVEs are 10 percent lower for RCCs (Table 4). Restricting attention to those townships for which repayment data exists for both institutions, we find that on average RCC household repayment is 4 percent higher $(n=38)$ and TVE repayment 6 percent lower $(n=24)$ than RCF loans, but that the standard errors are too large for these differences to be statistically significant. The earlier empirical results also found no improvement in TVE repayment under competition. Overall, the results are not conclusive, but we find weak support for RCFs having a relative advantage in administering household loans and for political motivations for TVE lending by RCCs. 
In the empirical tests, we have been unable to distinguish between the cases that obtain under competition, searching instead for general or average effects of competition, even though different cases may obtain in different townships. The most obvious difference between case 2 and case 3B, the game's likely outcomes, is the interest rate strategy pursued by the entrant. In case 2, the entrant sets a high interest rate and goes after the secondary pool while in case 3B (or 4B), he sets a lower interest rate and goes after the best borrowers. Recall that the incumbent exerts effort and captures the best borrowers in case 2, and does not exert effort or capture the best borrowers in case 3B. In Table 11, we present descriptive statistics dividing the sample of townships with RCFs into two groups based on the interest rate difference between the two institutions. The samples are small but the results are suggestive.

For townships with a small interest gap (16 townships), the RCF interest rate is one percent lower than that of RCCs on average. For townships with a large interest rate gap, the average gap is nearly 4 percent. The large gap townships tend to have a higher income per capita (by about 25 percent) and are more industrial, which would be expected to produce a better secondary pool of borrowers. There are some striking differences between the two groups. Effort indicators for RCCs (loans with no requirements, agent/staff ratio, and lawsuits) show substantially higher effort in the large gap group, consistent with the theory. Profits, TVE loan repayment rates, and TVE loan share are significantly higher, while the overdue loan rate is somewhat smaller. RCF loan performance (as seen in profits, repayment rates and overdues) also is superior in the large gap sample, with repayment rates for both TVE and household loans comparable to RCCs. The relative difference in loan composition between the two institutions in the large gap sample is higher, consistent with greater segmentation associated with a larger interest rate gap. However, in both cases, the share of household loans in RCFs is substantially higher, suggesting a comparative advantage (or preference) for household loans. RCF TVE repayment is much greater than RCC TVE repayment in the small interest group (and statistically significant), consistent with the entrants stealing the best customers in case 4. But we are unable to find repayment differences between RCCs and 
RCFs in any other context, suggesting that our predicted sharp separations by borrower quality are being blunted by other factors (ability and policy differences).

\section{Concluding Remarks}

In this paper, we have laid out a theoretical framework for better understanding the possible outcomes of competition in financially repressed systems by developing a duopoly model of financial competition. Multiple outcomes are possible, yielding different empirical predictions. We have studied the effects of competition empirically by analyzing data from rural financial institutions in China.

We conclude by emphasizing the beneficial effects of competition for improved financial performance, both by providing institutional diversity and by creating stronger effort incentives for incumbent banks. We have demonstrated the plausibility of such incentives theoretically under systems of credit rationing, and have provided empirical support for their existence in the case of financial competition in rural China. Rural credit cooperatives in rural China exert greater effort and perform better when facing competition from emerging rural cooperative foundations. RCFs also appear to have institutional advantages in making loans to rural households.

We believe potential improvement in the performance of existing banks has been largely overlooked in the debate over financial regulation in China, where incumbent banks loudly complain about the negative effects of competition on their earnings capability. The empirical results validate government concerns that RCFs steal deposits away from RCCs without mobilizing new deposits. If control over financial resources is the primary policy concern of government, it is not surprising that RCFs were regulated out of existence. However, such choices should be made with an accurate awareness of the costs. Also, while RCFs promote more efficient financial intermediation, they do not necessarily increase the total volume of lending for households or for all purposes; in fact the opposite may be true. Other potential policy concerns include reducing poorly performing loans to TVEs, and considering institutional innovations that can improve RCC performance in poorer, less industrial areas where RCFs choose not to locate. 


\section{References}

Banerjee, Abhijit, Timothy Besley, and Timothy Guinnane. 1994. "They Neighbor's Keeper: the Design of a Credit Cooperative with Theory and a Test," Quarterly Journal of Economics 491-515.

Bekker, Paul. 1994. "Alternative Approximations to the Distributions of Instrumental Variable Estimators," Econometrica 62: 657-681.

Besanko, David, and Anjan Thakor. 1987. "Collateral and Rationing: Sorting Equilibria in Monopolistic and Competitive Markets," International Economic Review 28: 671-689.

Besanko, David, and Anjan Thakor. 1993. "Relationship Banking, Deposit Insurance and Bank Portfolio Choice," in Colin Mayer and Xavier Vives, eds., Capital Markets and Financial Intermediation (Cambridge: Cambridge University Press), pp. 262-319.

Bose, Pinaki. 1998. "Formal-Informal Sector Interaction in Rural Credit Markets," Journal of Development Economics 56: 265-280.

Carter, Michael. 1988. "Equilibrium Credit Rationing of Small Farm Agriculture," Journal of Development Economics 28: 83-103.

Cheng Enjiang, Christopher Findlay, and Andrew Watson. 1997. "'We're Not Financial Organizations!': Financial Innovation without Regulation in China's Rural Credit Foundations," MOCT-MOST: Economic Policy in Transitional Economies 8(3): 41-55.

Claessens, Stijn. 1996. "Banking Reform in Transition Countries,” World Bank Policy Research Working Paper No. 1642.

Dinc, Serdar. 2000. "Bank Reputation, Bank Commitment, and the Effects of Competition in Credit Markets," Review of Financial Studies 13(3): 781-812.

Du, Zhixiong. 1998. "The Dynamics and Impact of the Development of Rural Cooperative Funds (RCFs) in China," Chinese Economies Research Center Working Paper No. 98/2, University of Adelaide.

Floro, Maria Sagario, and Debraj Ray. 1997. "Vertical Links Between Formal and Informal Financial Institutions," Review of Development Economics 1: 34-56.

Freixas, Xavier, and Jean-Charles Rochet. 1997. Microeconomics of Banking (Cambridge: The MIT Press). 
Fry, Maxwell. 1995. Money, Interest, and Banking in Economic Development (Baltimore: The Johns Hopkins University Press).

Gordon, Roger, and Wei Li. 1999. Government as a Discriminating Monopolist in the Financial Market: The Case of China, mimeo.

Hahn, Jinyong, and Atsushi Inoue. 1999. A Monte Carlo Comparison of Various Asymptotic Approximations to the Distribution of Instrumental Variables Estimators, mimeo.

He, Mingbing, Ya Huang, and Fucheng Liu. 1997. "Rural Credit Cooperative Problems of Risk Management (nongcun xinyongshe jingying fengxian wenti)," Sichuan Rural Finance 10.

Heckman, James, and Richard Robb. 1985. "Alternative Methods for Evaluating the Impact of Interventions," in James Heckman and Burton Singer, eds., Longitudinal Analysis of Labor Market Data (Cambridge, New York, and Sidney: Cambridge University Press, pp.158-245).

Heffernan, Shelagh. 1993. "Competition in British Retail Banking," Jounal of Financial Services Research 7(4): 309-32.

Heffernan, Shelagh. 1996. Modern Banking in Theory and Practice (New York: Wiley).

Hoff, Karla, and Joseph Stiglitz. 1998. "Moneylenders and Bankers: Price-Increasing Subsidies in a Monopolistically Competitive Market," Journal of Development Economics 55: 485-518.

Holz, Carsten. 2001. "China's Monetary Reform: The Counterrevolution from the Countryside," Journal of Contemporary China 10(27): 189-217.

Laffont, Jean-Jacques, and Jean Tirole. 1993. A Theory of Incentives in Procurement and Regulation (Cambridge: MIT Press).

Lardy, Nicholas. 1998. China's Unfinished Economic Revolution (Washington, D. C.: Brookings Institution).

Matten, Chris. 1996. Managing Bank Capital: Capital Allocation and Performance Measurement (Chichester: John Wiley \& Sons).

McKinnon, Ronald. 1973. Money and Capital in Economic Development (Washington, D.C.: Brookings Institution). 
Naughton, Barry, and John McMillan. 1992. "How to Reform a Planned Economy: Lessons from China," Oxford Review of Economic Policy 8(1): 130-143.

Park, Albert, and Kaja Sehrt. 2001. "Tests of Financial Intermediation and Banking Reform in China," Journal of Comparative Economics 29: 608-644.

Park, Albert, Loren Brandt, and John Giles. 1997. "Giving Credit Where Credit is Due: the Changing Role of Rural Financial Institutions in China," William Davidson Institute Working Paper No. 71, University of Michigan.

Peterson, Mitchell, and Raghuram Rajan. 1995. “The Effect of Credit Market Competition on Lending Relationships," Quarterly Journal of Economics 110(2): 407-443.

Riordan, Michael. 1993. "Competition and Bank Performance: A Theoretical Perspective," in Colin Mayer and Xavier Vives, eds., Capital Markets and Financial Intermediation (Cambridge: Cambridge University Press), pp. 328-343.

Sehrt, Kaja. 1999. "State Control of Urban Finance: the Incorporation of Credit Cooperatives in the PRC," paper presented at the Association for Asian Studies annual meeting, Boston.

Shen, Minggao. 1999. Banking Competition, Information Asymmetry, and Financial Intermediation in Rural China, mimeo.

Staiger, Doug, and James Stock. 1997. "Instrumental Variables Regression with Weak Instruments," Econometrica 65: 557-586.

Stiglitz, Joseph, and Andrew Weiss. 1981. "Credit Rationing in Markets with Imperfect Competition," American Economic Review 71(3): 393-410.

Tsai, Kelly. 1999. Financing Private Enterprises in China: A Political Economic View from Below, paper presented at the 1999 Association for Asian Studies annual meeting, Boston.

Villas-Boas, J., and U. Schmidt-Mohr. 1999. "Oligopoly with Asymmetric Information: Differentiation in Credit Markets," The RAND Journal of Economics 30(3): 375396.

Watson, Andrew. 1998. "Conflicts of Interest: Reform of the Rural Credit Cooperatives in China," MOCT-MOST: Economic Policy in Transitional Economies 8(3): 2340. 
Zhou, Shuiping, and Xiaolin Chen. 1998. "The Direction of Rural Credit Cooperative Reform (nongcun xinyong hezuoshe gaige fangxiang shenlun)," Jiangxi Social Science 2. 
Figure 1

Payoff Matrix for Effort by Entrant and Incumbent

\begin{tabular}{|c|c|c|c|}
\hline & & \multicolumn{2}{|c|}{ Incumbent } \\
\hline Entrant & & $\mathrm{e}_{\mathrm{I}}=0$ & $\mathrm{e}_{\mathrm{I}}=1$ \\
\hline $\mathrm{e}_{\mathrm{E}}=0$ & $\begin{array}{l}\text { Incumbent } \\
\text { Entrant }\end{array}$ & $\begin{array}{l}\text { CASE } 1 \\
\text { Borrower quality the same } \\
R_{I} E\left[\theta \mid \theta^{s} \leq \theta\right]-d_{I} \\
R_{E}^{s} E\left[\theta \mid \theta^{s} \leq \theta\right]-d_{E}\end{array}$ & $\begin{array}{l}\text { CASE } 2 \\
\text { Best borrowers to incumbent } \\
R_{\mathrm{I}} E\left[\theta \mid \theta_{\mathrm{I}} \leq \theta\right]-\mathrm{d}_{\mathrm{I}}-\mathrm{c}_{\mathrm{I}} \\
\mathrm{R}_{\mathrm{E}}^{\mathrm{s}} \mathrm{E}\left[\theta \mid \theta^{\mathrm{s}} \leq \theta \leq \theta_{\mathrm{I}}^{\mathrm{b}}\right]-\mathrm{d}_{\mathrm{E}}\end{array}$ \\
\hline $\mathrm{e}_{\mathrm{E}}=1$ & $\begin{array}{l}\text { Incumbent } \\
\text { Entrant } \\
\text { Incumbent } \\
\text { Entrant }\end{array}$ & $\begin{array}{l}\text { CASE 3A } \\
\text { Borrower quality the same } \\
\mathrm{R}_{\mathrm{I}} \mathrm{E}\left[\theta \mid \theta^{\mathrm{s}} \leq \theta\right]-\mathrm{d}_{\mathrm{I}} \\
\mathrm{R}_{\mathrm{E}}^{\mathrm{s}} \mathrm{E}\left[\theta \mid \theta^{\mathrm{s}} \leq \theta\right]-\mathrm{d}_{\mathrm{E}}-\mathrm{c}_{\mathrm{E}} \\
\text { CASE 3B } \\
\text { Best borrowers to entrant } \\
\mathrm{R}_{\mathrm{I}} \mathrm{E}\left[\theta \mid \theta^{\mathrm{s}} \leq \theta \leq \theta_{\mathrm{E}}^{\mathrm{b}}\right]-\mathrm{d}_{\mathrm{I}} \\
\mathrm{R}_{\mathrm{E}}{ }^{\mathrm{L}} \mathrm{E}\left[\theta \mid \theta_{\mathrm{E}}{ }^{\mathrm{b}} \leq \theta\right]-\mathrm{d}_{\mathrm{E}}-\mathrm{c}_{\mathrm{E}}\end{array}$ & $\begin{array}{l}\text { CASE 4A } \\
\text { Best borrowers to incumbent } \\
R_{I} E\left[\theta \mid \theta_{I}^{b} \leq \theta\right]-d_{I}-c_{I} \\
R_{E}{ }^{s} E\left[\theta \mid \theta^{s} \leq \theta \leq \theta_{I}^{b}\right]-d_{E}-c_{E} \\
\text { CASE 4B } \\
\text { Best borrowers to entrant } \\
R_{I} E\left[\theta \mid \theta^{s} \leq \theta \leq \theta_{E}^{b}\right]-d_{I}-c_{I} \\
R_{I} E\left[\theta \mid \theta_{E}{ }^{b} \leq \theta\right]-d_{E}-c_{E}\end{array}$ \\
\hline
\end{tabular}

Payoffs for Effort under Monopoly

\begin{tabular}{|c|l|l|l|}
\hline & & \multicolumn{1}{|c|}{$\mathrm{e}_{\mathrm{I}}=0$} & \multicolumn{1}{c|}{$\mathrm{e}_{\mathrm{I}}=1$} \\
\hline No entrant & Incumbent & $\mathrm{R}_{\mathrm{I}} \mathrm{E}\left[\theta \mid \theta^{\mathrm{m}} \leq \theta\right]-\mathrm{d}_{\mathrm{I}}$ & $\mathrm{R}_{\mathrm{I}} \mathrm{E}\left[\theta \mid \theta^{\mathrm{s}} \leq \theta\right]-\mathrm{d}_{\mathrm{I}}-\mathrm{c}_{\mathrm{I}}$ \\
\hline
\end{tabular}

Key orderings: $\theta_{\mathrm{E}}^{\mathrm{b}} \geq \theta_{\mathrm{I}}^{\mathrm{b}} \geq \theta^{\mathrm{s}} \geq \theta^{\mathrm{m}}\left(\theta_{\mathrm{E}}^{\mathrm{b}} \geq \theta_{\mathrm{I}}^{\mathrm{b}}\right.$ assumes $\left.\alpha<0.5\right) ; \mathrm{R}_{\mathrm{E}}^{\mathrm{s}} \geq \mathrm{R}_{\mathrm{E}}^{\mathrm{L}} \geq \mathrm{R}_{\mathrm{I}}$ 
Table 1

Sources and Uses of Funds for RCCs and RCFs in 1995 (\%)

\begin{tabular}{|c|c|c|c|c|}
\hline & All RCCs & $\begin{array}{l}\text { RCCs w/ } \\
\text { RCFs }\end{array}$ & RCCs w/out RCF & $\mathrm{RCFs}^{1}$ \\
\hline \multicolumn{5}{|l|}{ Sources: } \\
\hline Deposits & $\begin{array}{c}77.9 \\
(20.6)\end{array}$ & $\begin{array}{l}80.5 \\
(20.2)\end{array}$ & $\begin{array}{c}75.6 \\
(20.9)\end{array}$ & 100 \\
\hline Households & $\begin{array}{c}71.2 \\
(21.3)\end{array}$ & $\begin{array}{l}74.1 \\
(20.9)\end{array}$ & $\begin{array}{l}75.6 \\
(20.9)\end{array}$ & $\begin{array}{c}62.0 \\
(30.6)\end{array}$ \\
\hline Collective & $\begin{array}{c}6.7 \\
(9.1)\end{array}$ & $\begin{array}{c}6.4 \\
(7.3)\end{array}$ & $\begin{array}{c}6.9 \\
(21.5)\end{array}$ & $\begin{array}{l}25.1 \\
(29.2)\end{array}$ \\
\hline $\begin{array}{l}\text { Government and } \\
\text { other organizations }\end{array}$ & & & & $\begin{array}{c}7.5 \\
(14.2) \\
\end{array}$ \\
\hline \multicolumn{5}{|l|}{ Uses : } \\
\hline Total Loans & $\begin{array}{l}58.4 \\
(20.0)\end{array}$ & $\begin{array}{l}56.1 \\
(20.5)\end{array}$ & $\begin{array}{c}60.5 \\
(19.4)\end{array}$ & $\begin{array}{c}87.2 \\
(10.8)\end{array}$ \\
\hline \multicolumn{5}{|l|}{ of which: } \\
\hline Households & $\begin{array}{c}51.8 \\
(38.2)\end{array}$ & $\begin{array}{l}35.4 \\
(35.9)\end{array}$ & $\begin{array}{c}66.0 \\
(34.4)\end{array}$ & $\begin{array}{c}54.8 \\
(30.5)\end{array}$ \\
\hline TVEs & $\begin{array}{c}28.8 \\
(33.4)\end{array}$ & $\begin{array}{l}40.2 \\
(36.2)\end{array}$ & $\begin{array}{l}19.0 \\
(27.4)\end{array}$ & $\begin{array}{c}18.2 \\
(18.6)\end{array}$ \\
\hline Commercial $^{2}$ & $\begin{array}{l}15.9 \\
(23.2)\end{array}$ & $\begin{array}{c}20.6 \\
(22.9)\end{array}$ & $\begin{array}{l}11.9 \\
(22.9)\end{array}$ & $\begin{array}{c}9.9 \\
(13.9)\end{array}$ \\
\hline Held in other & 24.3 & 27.8 & 21.3 & 12.8 \\
\hline Financial Institutions & $(18.5)$ & $(20.9)$ & $(15.8)$ & $(10.8)$ \\
\hline Other & $\begin{array}{c}17.2 \\
(14.1) \\
\end{array}$ & $\begin{array}{c}16.1 \\
(12.0) \\
\end{array}$ & $\begin{array}{c}18.2 \\
(15.8) \\
\end{array}$ & 0.0 \\
\hline Loan-Deposit Ratio $^{3}$ & $\begin{array}{c}0.821 \\
(0.450)\end{array}$ & $\begin{array}{c}0.758 \\
(0.465) \\
\end{array}$ & $\begin{array}{c}0.875 \\
(0.434) \\
\end{array}$ & $\begin{array}{c}0.872 \\
(0.108)\end{array}$ \\
\hline
\end{tabular}

Notes: 1. In RCFs, the deposits actually represent shares. 2. Commercial loans from RCFs are mainly to publicly-owned enterprises, while those from RCFs are to private entrepreneurs (getihu). 3. Loan-deposit rates truncated at 2 (affecting 6 observations). 
Table 2

1988 Characteristics of Townships Where RCFs Were and Were Not Established

\begin{tabular}{lcc}
\hline & Townships w/ & Townships w/out \\
& RCF & RCF \\
\hline Income Per Capita (yuan) & 1146 & 893 \\
& $(631)$ & $(423)$ \\
Population (1000s) & 22.0 & 21.9 \\
& $(10.5)$ & $(14.4)$ \\
Industrial Share of Income (\%) & 32.9 & 26.6 \\
& $(24.0)$ & $(21.6)$ \\
Informal Loan Market (\% Total Household Loan & 59.5 & 61.6 \\
Number) & $(23.8)$ & $(24.9)$ \\
Of which: At positive interest (\%) & 7.26 & 5.86 \\
& $(12.9)$ & $(17.5)$ \\
\hline
\end{tabular}

Table 3

RCF Establishment Proportional Hazard Model Estimates Dependent Variable $=\mathbf{R C F}_{\mathrm{t}}$

\begin{tabular}{lc}
\hline & Coefficient \\
\hline $\log \left(\mathrm{CINCPC}_{\mathrm{t}-1}\right)$ & 0.165 \\
& $(0.518)$ \\
$\mathrm{CINCG}_{\mathrm{t}-1}$ & 0.820 \\
& $(0.911)$ \\
$\mathrm{CINDSH}_{\mathrm{t}-1}$ & 3.24 \\
& $(1.72)$ \\
$\log \left(\mathrm{CPOP}_{\mathrm{t}-1}\right)$ & 0.567 \\
& $(0.373)$ \\
\hline $\mathrm{N}$ & 86 \\
Failures & 46 \\
Periods at Risk & 591 \\
\hline
\end{tabular}

Note: Includes data from 7 provinces which have RCFs and for which time of establishment is observed for at least one RCF. Robust standard errors. 
Table 4

Performance Indicators for RCCs and RCFs

\begin{tabular}{|c|c|c|c|c|}
\hline & ALL RCC & $\begin{array}{c}\text { RCC } \\
\mathrm{W} / \mathrm{RCF}\end{array}$ & $\begin{array}{c}\text { RCC } \\
\text { W/OUT } \\
\text { RCF }\end{array}$ & $\mathrm{RCF}$ \\
\hline $\begin{array}{l}\text { 1994-95 Deposit Increase Per Capita } \\
\text { (yuan) }\end{array}$ & $\begin{array}{c}106 \\
(124)\end{array}$ & $\begin{array}{c}119 \\
(113)\end{array}$ & $\begin{array}{l}93.3 \\
(134)\end{array}$ & $\begin{array}{l}31.7 \\
(115)\end{array}$ \\
\hline 1994-95 Deposit Growth (\%) & $\begin{array}{c}11.1 \\
(18.1)\end{array}$ & $\begin{array}{c}9.15 \\
(15.4)\end{array}$ & $\begin{array}{c}12.9 \\
(20.2)\end{array}$ & $\begin{array}{l}80.4^{*} \\
(148.2)\end{array}$ \\
\hline 1995 Deposits per Capita (yuan) & $\begin{array}{c}268 \\
(345)\end{array}$ & $\begin{array}{c}377 \\
(432)\end{array}$ & $\begin{array}{c}175 \\
(210)\end{array}$ & $\begin{array}{c}93 \\
(154)\end{array}$ \\
\hline 1995 Deposit Share (\%) & 100 & $\begin{array}{c}92 \\
(16)\end{array}$ & 100 & $\begin{array}{l}18 \\
(16)\end{array}$ \\
\hline $\begin{array}{l}1995 \text { Intermediation Rate } \\
\text { (loans/gross output value) (\%) }\end{array}$ & $\begin{array}{c}11.2 \\
(15.1)\end{array}$ & $\begin{array}{c}7.22 \\
(7.43)\end{array}$ & $\begin{array}{c}14.3 \\
(18.5)\end{array}$ & $\begin{array}{l}1.88 \\
(2.57)\end{array}$ \\
\hline 1988 Before-Tax Profitability ${ }^{1}(\%)$ & $\begin{array}{l}1.22 \\
(2.10)\end{array}$ & $\begin{array}{c}1.13 \\
(1.23)\end{array}$ & $\begin{array}{l}1.31 \\
(2.72)\end{array}$ & \\
\hline 1988 Percent RCCs w/ profits $<0$ & 6.4 & 2.6 & 10.3 & \\
\hline 1995 Before-Tax Profitability (\%) & $\begin{array}{l}0.796 \\
(3.02)\end{array}$ & $\begin{array}{l}0.285 \\
(2.77)\end{array}$ & $\begin{array}{l}1.25 \\
(3.18)\end{array}$ & $\begin{array}{c}4.1 \\
(5.1)\end{array}$ \\
\hline 1995 Percent RCCs w/ profits $<0$ & 19.6 & 14.6 & 24.1 & 0 \\
\hline 1995 Overdue Loans ${ }^{2}(\%)$ & $\begin{array}{c}33.9 \\
(25.9)\end{array}$ & $\begin{array}{c}28.4 \\
(26.0)\end{array}$ & $\begin{array}{c}39.2 \\
(24.9)\end{array}$ & $\begin{array}{c}18.5 \\
(22.8)\end{array}$ \\
\hline 1995 Timely Repayment Rates & & & & \\
\hline Households $(\%)$ & $\begin{array}{c}72.1 \\
(27.3)\end{array}$ & $\begin{array}{c}77.2 \\
(25.2)\end{array}$ & $\begin{array}{c}67.6 \\
(28.4)\end{array}$ & $\begin{array}{l}76.7 \\
(26.3)\end{array}$ \\
\hline TVEs (\%) & $\begin{array}{c}59.0 \\
(37.0)\end{array}$ & $\begin{array}{c}60.5 \\
(37.8)\end{array}$ & $\begin{array}{c}57.1 \\
(36.7)\end{array}$ & $\begin{array}{c}71.0 \\
(30.7)\end{array}$ \\
\hline
\end{tabular}

Notes: *Median growth rate for RCF deposits was 45.6 percent. 1. Profitability is measured as a percentage of gross income, and truncated at 10 percent (affecting 3 observations). 2. Overdue loans are loans overdue as a percentage of total loans. 


\section{Table 5}

\section{Competition and Deposit Growth \\ (LIMLK-IV)}

\begin{tabular}{lcccc}
\hline & \multicolumn{2}{c}{$\begin{array}{c}\text { RCC deposit change } \\
\text { per capita }\end{array}$} & \multicolumn{2}{c}{ Total deposit change } \\
per capita
\end{tabular}

All regressions include provincial and year dummy variables ( 8 observations report 1996 instead of 1995 data). OLS estimates are from separate regressions with identical specification. The instrumental variables are county industrial share of income in the year before RCFs first appeared in the province interacted with provincial dummies in provinces that have RCFs. Variables are defined as follows: RCF--dummy for RCF presence, RCFDS - share of villager deposits in RCF (from village survey form), INCPC — income per capita, DEPPC — deposits per capita at the beginning of the year, and INDSH - township industrial share of output value. 
Table 6

Competition and RCC Loan Composition

(LIMLK-IV)

\begin{tabular}{|c|c|c|c|c|c|c|c|c|}
\hline & TVSH95 & $\begin{array}{l}\text { TVSH95- } \\
\text { TVSH88 }\end{array}$ & TVSH95 & $\begin{array}{l}\text { TVSH95- } \\
\text { TVSH88 }\end{array}$ & HHSH95 & $\begin{array}{l}\text { HHSH95- } \\
\text { HHSH88 }\end{array}$ & HHSH95 & $\begin{array}{l}\text { HHSH95- } \\
\text { HHSH88 }\end{array}$ \\
\hline$\overline{\mathrm{RCF}}$ & $\begin{array}{c}0.3109 \\
(0.0973)\end{array}$ & $\begin{array}{c}0.1641 \\
(0.0779)\end{array}$ & & & $\begin{array}{l}-0.3141 \\
(0.1008)\end{array}$ & $\begin{array}{l}-0.2158 \\
(0.0770)\end{array}$ & & \\
\hline RCFDS & & & $\begin{array}{c}1.2932 \\
(0.4922)\end{array}$ & $\begin{array}{c}0.7503 \\
(0.4615)\end{array}$ & & & $\begin{array}{l}-1.2183 \\
(0.7982)\end{array}$ & $\begin{array}{l}-0.6358 \\
(0.6943)\end{array}$ \\
\hline TVESH88 & $\begin{array}{c}0.5075 \\
(0.1294)\end{array}$ & & $\begin{array}{c}0.7215 \\
(0.1215)\end{array}$ & & & & & \\
\hline HHSH88 & & & & & $\begin{array}{c}0.6247 \\
(0.1246)\end{array}$ & & $\begin{array}{c}0.7247 \\
(0.1211)\end{array}$ & \\
\hline $\begin{array}{l}\text { LOG(INCPC95) } \\
\text { [-LOG(INCPC } 88)]\end{array}$ & 0.0836 & -0.1132 & 0.0713 & -0.0932 & -0.1060 & -0.0547 & -0.1260 & -0.0811 \\
\hline INDSH95[-INDSH88] & $\begin{array}{c}(0.0565) \\
0.0409 \\
(0.1109) \\
\end{array}$ & $\begin{array}{c}(0.0605) \\
0.0944 \\
(0.1325) \\
\end{array}$ & $\begin{array}{c}(0.0599) \\
-0.0812 \\
(0.1289) \\
\end{array}$ & $\begin{array}{c}(0.0592) \\
0.0532 \\
(0.1487)\end{array}$ & $\begin{array}{c}(0.0586) \\
0.0461 \\
(0.1262) \\
\end{array}$ & $\begin{array}{c}(0.0630) \\
0.1005 \\
(0.1373) \\
\end{array}$ & $\begin{array}{c}(0.0590) \\
0.1350 \\
(0.1443) \\
\end{array}$ & $\begin{array}{c}(0.0600) \\
0.1041 \\
(0.1748) \\
\end{array}$ \\
\hline$\overline{\mathrm{RCF}}(\mathrm{OLS})$ & $\begin{array}{c}0.0591 \\
(0.0411)\end{array}$ & $\begin{array}{c}0.0318 \\
(0.0402)\end{array}$ & & & $\begin{array}{l}-0.0950 \\
(0.0477)\end{array}$ & $\begin{array}{l}-0.0837 \\
(0.0422)\end{array}$ & & \\
\hline RCFDS (OLS) & & & $\begin{array}{r}0.3222 \\
(0.1440) \\
\end{array}$ & $\begin{array}{r}0.2697 \\
(0.1451) \\
\end{array}$ & & & $\begin{array}{l}-0.4184 \\
(0.1708) \\
\end{array}$ & $\begin{array}{l}-0.3600 \\
(0.1557) \\
\end{array}$ \\
\hline$\overline{\mathrm{N}}$ & 94 & 94 & 89 & 89 & 81 & 81 & 81 & 81 \\
\hline F-stat (1 st stage) & 3.64 & 3.43 & 2.80 & 2.61 & 4.19 & 4.59 & 2.94 & 2.63 \\
\hline F-stat (p-value) & 0.001 & 0.002 & 0.010 & 0.017 & 0.000 & 0.000 & 0.007 & 0.016 \\
\hline Basmann $\chi^{2}$ (p-value) & 0.843 & 0.500 & 0.413 & 0.361 & 0.789 & 0.849 & 0.068 & 0.105 \\
\hline Durban stat. (p-value) & 0.000 & 0.012 & 0.013 & 0.253 & 0.001 & 0.040 & 0.302 & 0.693 \\
\hline AR stat. (p-value) & 0.011 & 0.201 & 0.007 & 0.158 & 0.032 & 0.140 & 0.021 & 0.107 \\
\hline
\end{tabular}

Notes: Provincial dummies jointly insignificant and are excluded. Bracketed terms are included in difference regressions. OLS estimates are from separate regressions with identical specification. 
Table 7

Competition and Total Loan Composition

(LIMLK-IV)

\begin{tabular}{|c|c|c|c|c|c|c|c|c|}
\hline & TVSH95 & $\begin{array}{l}\text { TVSH95- } \\
\text { TVSH88 }\end{array}$ & TVSH95 & $\begin{array}{l}\text { TVSH95- } \\
\text { TVSH88 }\end{array}$ & HHSH95 & $\begin{array}{l}\text { HHSH95- } \\
\text { HHSH88 }\end{array}$ & HHSH95 & $\begin{array}{l}\text { HHSH95- } \\
\text { HHSH88 }\end{array}$ \\
\hline$\overline{\mathrm{RCF}}$ & $\begin{array}{c}0.1665 \\
(0.0852)\end{array}$ & $\begin{array}{c}0.0382 \\
(0.0726)\end{array}$ & & & $\begin{array}{l}-0.2550 \\
(0.3980)\end{array}$ & $\begin{array}{l}-0.1909 \\
(0.0831)\end{array}$ & & \\
\hline RCFDS & & & $\begin{array}{c}0.3379 \\
(0.3541)\end{array}$ & $\begin{array}{c}0.0038 \\
(0.4053)\end{array}$ & & & $\begin{array}{l}-2.5300 \\
(3.1400)\end{array}$ & $\begin{array}{l}-0.6676 \\
(0.5418)\end{array}$ \\
\hline TVESH88 & $\begin{array}{c}0.5521 \\
(0.1205)\end{array}$ & & $\begin{array}{c}0.6722 \\
(0.0926)\end{array}$ & & & & & \\
\hline HHSH88 & & & & & $\begin{array}{l}0.637 \\
0.201\end{array}$ & & $\begin{array}{l}0.684 \\
0.194\end{array}$ & \\
\hline $\begin{array}{l}\text { LOG(INCPC95) } \\
\text { [-LOG(INCPC } 88)]\end{array}$ & 0.0857 & -0.0635 & 0.0867 & -0.0566 & -0.0332 & -0.0590 & 0.1820 & -0.0897 \\
\hline INDSH95[-INDSH88] & $\begin{array}{c}(0.0443) \\
0.0612 \\
(0.0890) \\
\end{array}$ & $\begin{array}{c}(0.0542) \\
0.0980 \\
(0.1193) \\
\end{array}$ & $\begin{array}{c}(0.0417) \\
0.0406 \\
(0.0859) \\
\end{array}$ & $\begin{array}{c}(0.0520) \\
0.1149 \\
(0.1291) \\
\end{array}$ & $\begin{array}{c}(0.1380) \\
0.0089 \\
(0.1340) \\
\end{array}$ & $\begin{array}{c}(0.0680) \\
0.1085 \\
(0.1491) \\
\end{array}$ & $\begin{array}{c}(0.3810) \\
0.0715 \\
(0.1980) \\
\end{array}$ & $\begin{array}{c}(0.0668) \\
0.1322 \\
(0.1670) \\
\end{array}$ \\
\hline RCF (OLS) & $\begin{array}{c}0.0209 \\
(0.0410)\end{array}$ & $\begin{array}{l}-0.0066 \\
(0.0394)\end{array}$ & & & $\begin{array}{c}0.0078 \\
(0.0692)\end{array}$ & $\begin{array}{l}-0.0522 \\
(0.0463)\end{array}$ & & \\
\hline RCFDS (OLS) & & & $\begin{array}{c}0.0871 \\
(0.1474) \\
\end{array}$ & $\begin{array}{c}0.0072 \\
(0.1538) \\
\end{array}$ & & & $\begin{array}{l}-0.1080 \\
(0.2060) \\
\end{array}$ & $\begin{array}{r}-0.1349 \\
(0.1852) \\
\end{array}$ \\
\hline$\overline{\mathrm{N}}$ & 70 & 70 & 70 & 70 & 71 & 71 & 71 & 71 \\
\hline F-stat (1st stage) & 3.62 & 6.51 & 3.35 & 3.89 & 2.32 & 6.53 & 1.21 & 3.95 \\
\hline F-stat (p-value) & 0.002 & 0.000 & 0.003 & 0.002 & 0.040 & 0.000 & 0.316 & 0.002 \\
\hline Basmann $\chi^{2}$ (p-value) & 0.884 & 0.150 & 0.453 & 0.132 & 0.112 & 0.368 & 0.350 & 0.084 \\
\hline Durban stat. (p-value) & 0.004 & 0.415 & 0.431 & 0.993 & 0.147 & 0.017 & 0.201 & 0.293 \\
\hline AR stat. (p-value) & 0.441 & 0.222 & 0.441 & 0.222 & 0.137 & 0.066 & 0.137 & 0.066 \\
\hline
\end{tabular}


Table 8

Competition and RCC Loan Repayment (LIMLK-IV)

\begin{tabular}{lcccccc}
\hline & OVER & OVER & TVEREP95 & TVEREP95 & HHREP95 & HHREP95 \\
\hline RCF & -0.3311 & & -0.0426 & & 0.2072 & \\
& $(0.3122)$ & & $(0.2576)$ & & $(0.3550)$ & \\
RCFDS & & -1.4432 & & 0.8415 & & 1.4295 \\
& & $(1.1959)$ & & $(1.5860)$ & & $(3.6206)$ \\
LOG(INCPC95) & 0.0245 & -0.0211 & 0.0557 & 0.0095 & 0.0989 & 0.0713 \\
& $(0.1580)$ & $(0.1313)$ & $(0.1519)$ & $(0.1765)$ & $(0.1413)$ & $(0.2541)$ \\
INDSH95 & 0.0674 & 0.1857 & -0.0295 & -0.1639 & -0.1675 & -0.2880 \\
& $(0.1298)$ & $(0.1794)$ & $(0.2381)$ & $(0.3380)$ & $(0.1322)$ & $(0.3928)$ \\
\hline RCF (OLS) & -0.0381 & & -0.1350 & & 0.0880 & \\
& $(0.0657)$ & & $(0.1250)$ & & $(0.0769)$ & \\
RCFDS (OLS) & & -0.0199 & & -0.2644 & & 0.0718 \\
& & $(0.2032)$ & & $(0.3337)$ & & $(0.2385)$ \\
\hline N & 94 & 92 & 64 & 64 & 90 & 88 \\
F-stat (1st stage) & 2.60 & 2.05 & 3.71 & 1.38 & 2.67 & 1.65 \\
F-stat (p-value) & 0.019 & 0.060 & 0.003 & 0.236 & 0.017 & 0.137 \\
Basmann $\chi^{2}$ (p-value) & 0.165 & 0.263 & 0.519 & 0.590 & 0.131 & 0.148 \\
Durban stat. (p-value) & 0.002 & 0.116 & 0.460 & 0.410 & 0.362 & 0.664 \\
AR stat. (p-value) & 0.122 & 0.120 & 0.634 & 0.634 & 0.175 & 0.182 \\
\hline
\end{tabular}

Notes: includes provincial and year dummy variables. OLS estimates are from separate regressions with identical specification. 
Table 9

Governance in Rural Financial Institutions

\begin{tabular}{lcccc}
\hline & All RCCs & $\begin{array}{c}\text { RCCs } \\
\text { w/RCFs }\end{array}$ & $\begin{array}{c}\text { RCCs w /out } \\
\text { RCFs }\end{array}$ & RCFs \\
\hline No borrowing & 26.7 & 19.8 & 34.6 & 3.33 \\
requirements & $(33.7)$ & $(30.3)$ & $(35.8)$ & $(6.22)$ \\
(\% of institutions) & & & & \\
Agents/staff ratio & 0.314 & 0.284 & 0.340 & $0.690 *$ \\
& $(0.112)$ & $(0.105)$ & $(0.114)$ & $(2.04)$ \\
Lawsuits Last 3 Years: & 29.8 & 32.6 & 27.3 & 2.85 \\
& $(41.2)$ & $(47.1)$ & $(35.5)$ & $(7.56)$ \\
Employees: & 15.8 & 18.7 & 13.4 & 8.41 \\
& $(11.3)$ & $(13.2)$ & $(8.80)$ & $(13.8)$ \\
of which agents & 4.83 & 5.39 & 4.35 & 2.97 \\
& $(3.60)$ & $(4.18)$ & $(2.97)$ & $(10.3)$ \\
Loans per employee & 503 & 565 & 449 & 433 \\
(in 1000 RMB) & $(548)$ & $(482)$ & $(598)$ & $(636)$ \\
Wages/employee & 4.59 & 4.74 & 4.47 & 6.78 \\
(1000 RMB) & $(1.91)$ & $(1.61)$ & $(2.15)$ & $(1.65)$ \\
Administrative & 9.16 & 9.83 & 8.58 & 10.2 \\
costs/employee & $(12.7)$ & $(10.3)$ & $(1.29)$ & $(4.17)$ \\
\hline
\end{tabular}

*Excluding one RCF with a ratio of 14 reduces the mean to 0.41 , excluding all ratios greater than 1 (8 observations) reduces mean to 0.18 . 
Table 10

Competition and RCC Screening and Enforcement Effort (LIMLK-IV)

\begin{tabular}{|c|c|c|c|c|c|c|}
\hline & NOREQ & NOREQ & AGENTS & AGENTS & LAWSUITS & $\begin{array}{l}\text { LAWSUITS } \\
\end{array}$ \\
\hline$\overline{\mathrm{RCF}}$ & $\begin{array}{l}-27.2 \\
(27.6)\end{array}$ & & $\begin{array}{c}0.164 \\
(0.0946)\end{array}$ & & $\begin{array}{c}86.3 \\
(145)\end{array}$ & \\
\hline RCFDS & & $\begin{array}{c}-167 \\
(79.0)\end{array}$ & & $\begin{array}{c}0.354 \\
(0.860)\end{array}$ & & $\begin{array}{c}1039 \\
(1998)\end{array}$ \\
\hline LOG(INCPC95) & $\begin{array}{l}-7.79 \\
(13.7)\end{array}$ & $\begin{array}{c}110 \\
(0.0672)\end{array}$ & $\begin{array}{l}-0.0763 \\
(0.0525)\end{array}$ & $\begin{array}{l}-0.0351 \\
(0.0694)\end{array}$ & $\begin{array}{l}-75.2 \\
(67.5)\end{array}$ & $\begin{array}{c}-127 \\
(190)\end{array}$ \\
\hline INDSH95 & $\begin{array}{c}14.6 \\
(16.0)\end{array}$ & $\begin{array}{l}-7.21 \\
(12.6)\end{array}$ & $\begin{array}{l}-0.0226 \\
(0.0533)\end{array}$ & $\begin{array}{l}-0.0424 \\
(0.0876)\end{array}$ & $\begin{array}{c}9.19 \\
(49.0)\end{array}$ & $\begin{array}{c}61.5 \\
(165)\end{array}$ \\
\hline HHREP95 & & & & & $\begin{array}{l}-28.8 \\
(29.1)\end{array}$ & $\begin{array}{l}-63.0 \\
(110)\end{array}$ \\
\hline TVEREP95 & & & & & $\begin{array}{l}-14.4 \\
(65.4) \\
\end{array}$ & $\begin{array}{r}-145 \\
(332) \\
\end{array}$ \\
\hline$\overline{\mathrm{RCF}}(\mathrm{OLS})$ & $\begin{array}{l}-10.3 \\
(9.51)\end{array}$ & & $\begin{array}{c}0.0309 \\
(0.0275)\end{array}$ & & $\begin{array}{c}18.0 \\
(16.5)\end{array}$ & \\
\hline RCFDS (OLS) & & $\begin{array}{l}-35.6 \\
(27.4) \\
\end{array}$ & & $\begin{array}{c}0.102 \\
(0.0880) \\
\end{array}$ & & $\begin{array}{r}97.3 \\
(40.8) \\
\end{array}$ \\
\hline$\overline{\mathrm{N}}$ & 87 & 85 & 100 & 98 & 95 & 58 \\
\hline F-stat (1st stage) & 3.12 & 1.76 & 2.58 & 1.78 & 2.28 & 1.08 \\
\hline F-stat (p-value) & 0.007 & 0.110 & 0.019 & 0.104 & 0.050 & 0.397 \\
\hline Basmann $\chi^{2}$ (p-value) & 0.367 & 0.689 & 0.573 & 0.175 & 0.051 & 0.314 \\
\hline Durban stat. (p-value) & 0.075 & 0.128 & 0.000 & 0.729 & 0.401 & 0.518 \\
\hline AR stat. (p-value) & 0.350 & 0.348 & 0.216 & 0.227 & 0.065 & 0.065 \\
\hline
\end{tabular}

Note: Provincial dummy variables jointly significant and included. OLS estimates are from separate regressions with identical specification. 
Table 11

Interest Rate Differences and Performance

\begin{tabular}{|c|c|c|c|c|}
\hline & \multicolumn{2}{|c|}{ Small Interest Gap } & \multicolumn{2}{|c|}{ Large Interest Gap } \\
\hline & $\mathrm{RCC}$ & $\mathrm{RCF}$ & $\mathrm{RCC}$ & $\mathrm{RCF}$ \\
\hline Interest rate & 0.176 & 0.165 & 0.172 & 0.209 \\
\hline Profits (before-tax) & -0.61 & 3.72 & 1.06 & 5.22 \\
\hline Timely repayment-HH loans & 0.79 & 0.74 & 0.81 & 0.80 \\
\hline Timely repayment-TVE loans & 0.41 & 0.71 & 0.78 & 0.73 \\
\hline Overdue loans & 0.31 & 0.27 & 0.24 & 0.11 \\
\hline Household loan share & 0.40 & 0.59 & 0.28 & 0.54 \\
\hline TVE loan share & 0.34 & 0.15 & 0.53 & 0.18 \\
\hline Loan-deposit ratio & 0.60 & 0.85 & 0.81 & 0.88 \\
\hline Loans w/o guarantor/collateral & 0.31 & 0.09 & 0.15 & 0.03 \\
\hline $\begin{array}{l}\text { Decentralization- } \\
\text { village agents/township staff }\end{array}$ & 0.35 & 1.21 & 0.51 & 0.37 \\
\hline Lawsuits & 19 & 8 & 30 & $\mathbf{1}$ \\
\hline Loans per worker & 51 & 33 & 49 & 62 \\
\hline Income per capita & \multicolumn{2}{|c|}{1382} & \multicolumn{2}{|c|}{1710} \\
\hline Industrial share of income & \multicolumn{2}{|c|}{0.51} & \multicolumn{2}{|c|}{0.59} \\
\hline
\end{tabular}

Note: Groups are divided based on whether interest rate gap (RCF interest rate-RCC interest rate) is more or less than 0.5 percent. Bold denotes means for the two groups are statistically different than zero based on one-sided 95 percent confidence interval. Sample sizes are 16 (small gap) and 21 (large gap). Number of valid observations for specific variables range from 816 and $14-21$. 
${ }^{1}$ Empirical studies of financial competition generally take market structure to be exogenous and find that higher concentration ratios lead to higher profits and non-competitive pricing behavior (Heffernan, 1996). It is easy to imagine plausible ways in which concentration is endogenous, such as through intrinsic differences in efficiency that lead to both higher profits and higher concentration. Changes in official regulations governing entry and competition allow for more convincing identification, but if such changes are national in scope, it may be difficult to separate the effects of new regulations from other time-varying factors. See Heffernan (1993) for a study of British competition reforms.

${ }^{2}$ Several papers have examined vertical linkages between formal and informal lenders (Floro and Ray, 1997; Hoff and Stiglitz, 1998; and Bose, 1998). Bose describes "composition effects" of an informal lender's decisions (affected by formal credit access) on the portfolio quality of another informal lender, which is similar to the effects we describe from competition between a formal lender and a competitor.

${ }^{3}$ For example, strict controls over equity markets (both the stock market (Gordon and Li, 1999) and private brokering of equity shares or enterprise bonds), restrictions on establishment of private banks or credit societies (Tsai, 1999).

${ }^{4}$ RCFs have been criticized for inadequate risk provisions (Cheng, Findlay, and Watson, 1997).

${ }^{5}$ Competition among state commercial banks was promoted in 1992 (Shen, 1999). In 1999, the government pledged its support for regional banks supporting the private sector.

${ }^{6}$ From 1993 to 1996 the official annual interest rate on 6-month working capital loans was 9 percent, on annual loans 10 percent. CPI inflation was 15 percent in 1993, 24 percent in 1994, and 17 percent in 1995. Despite the inflation, during these 3 years, real GDP grew by an average of 13 percent per year (all data from the Statistical Yearbook of China). Village surveys find that informal loan rates are 40 percent higher than formal interest rates and rural household surveys find that reservation interest rates of rural households are well above official rates (Brandt, Giles, and Park, 1997). Many local managers complained that the low interest rates made it difficult to earn money.

${ }^{7}$ A minimum application cost is plausibly exogenous, but lenders could increase $\eta$ to screen borrowers strategically and earn higher returns. Allowing banks to use application costs to circumvent interest rate regulations subverts the goal of modeling competition under regulation. We argue that discretion to impose fees is limited in China, where enterprises are publicly owned and so local governments have an incentive to police against arbitrary fees. Later, we further defend the assumption that regulatory enforcement of interest rates has bite.

${ }^{8}$ The borrower is free to approach the other bank if his application is turned down, although when effort is exerted, there will usually be sorting between banks by type.

${ }^{9}$ Although we do not explicitly model collateral, to the extent that collateral or guarantor requirements necessitate complementary effort (to assess collateral value or credibly signal a willingness to seize assets), collateral and other monitoring activity, can be considered types of screening effort. Collateral tends to be less important in many developing countries where legal and other institutions are underdeveloped.

${ }^{10}$ This assumption rules out mixed strategy equilibria in which the bank screens with a probability less than one. This may be true for organizational or technological reasons, and accords well with institutional practice (which focuses on set procedures rather than random checks).

${ }^{11}$ First, part of any screening effort by banks will be to learn more about the borrower through visits, interviews, and the collection of relevant data on the borrowers business and proposed project. Such activities require the assistance or participation of the borrower. Second, banks will have an incentive to credibly convey information that they are screening to potential borrowers to attract good customers, and customers can easily verify the truth of such claims. In township communities, local government officials, bankers, and managers know each other well, so it is likely that firm managers have good information on local banking practices.

${ }^{12}$ Banks often treat deposit and loan services as distinct. See, for example, Matten (1996).

${ }^{13}$ In the monopoly case, a non-binding deposit constraint means that $\theta^{\mathrm{s}}$ is not determined by the fund balance condition $G\left(\theta^{s}\right)=D$, but rather by the profitability criteria $R_{I} \theta^{s}-d_{I}-c_{I}=0$. Under competition, when the incumbent does not exert effort (case 1 and case 3 ), she cannot distinguish among types and must lend to all applicants or to none. Although cessation of lending is possible, avoiding 
this degenerate case requires an assumption that lending to average types remains profitable even when the incumbent is left with the secondary borrowing pool. In cases 2 and 4 , lending could fall below deposits if there are insufficient good projects when the incumbent knows the quality of all projects. Thus, barring a cessation of lending a reduction in lending under competition may indicate that screening effort has increased.

${ }^{14}$ Administrative supervision was transferred from the Agricultural Bank of China (ABC) to the People's Bank of China in 1996.

${ }^{15}$ The remainder of deposits are held in Rural Cooperative Foundations (RCFs) and state banks, mainly the Agricultural Bank of China, which has branch offices in many but not all townships.

${ }^{16}$ State banks are more highly regulated than RCCs and have no obvious institutional advantages. They are also until recently enjoyed administrative oversight over RCCs, dampening incentives to compete.

${ }^{17}$ Officials at township agricultural economic management stations organize RCFs, usually drawing staff from township officials and village accountants. In Sichuan, each RCF had a charter of rules, a board of directors with a chairman (usually a township leader or agricultural monitoring official), and a managing director. Loans of 50,000 to 100,000 yuan required approval from the county agricultural monitoring station. Some areas also had county level RCFs (lianhehui, or united RCFs) whose purpose was to guarantee the security of township RCFs by brokering funds from other township RCFs. Beginning in 1994, new county level RCFs were prohibited because their lack of direct lending to households made it difficult to justify them as farmer service organizations (rather than new financial institutions).

${ }^{18}$ Provinces include Zhejiang, Sichuan, Hubei, Shaanxi, Shandong, Yunnan, Hebei, Liaoning, Gansu, Henan, Guizhou, and Jiangxi.

${ }^{19}$ The share of deposits in RCFs is measured using deposit data from the two financial institutions. When this data is unavailable, it is measured by the relative share of household deposits held in RCFs as reported in village surveys in the township.

${ }^{20}$ Interview with official in charge of RCFs, Ministry of Agriculture, Sichuan Province, April, 1996.

${ }^{21}$ The percentage of surveyed townships reporting RCFs was 92 percent in Sichuan, 67 percent in Liaoning, 63 percent in Shandong, 50 percent in Zhejiang and Guizhou, 43 percent in Jiangxi, 38 percent in Hebei, 25 percent in Yunnan, 13 percent in Hubei, 5 percent in Shaanxi, and zero percent in Gansu and Henan. ${ }^{22}$ The weakness of our instruments is not surprising given our small sample size and the elapsed time between initial introduction of RCFs in the province and the decision to establish RCFs.

${ }^{23}$ The asymptotically derived expectation and standard error of the 2SLS estimator treat the first-stage regression coefficients in the regression as fixed, implicitly assuming that the F-statistic increases to infinity with the sample size. The asymptotic standard errors of the limited information maximum likelihood estimator remains consistent even when the F-statistic converges to a finite number.

${ }^{24}$ Bekker's derives asymptotic standard errors for the case in which the number of instruments increases to infinity with sample size (which also creates weak correlation between the instruments and the endogenous variable). Hahn and Inoue compare the accuracy of different asymptotic assumptions (including the Anderson-Rubin confidence intervals proposed by Staiger and Stock) for finite samples by conducting Monte Carlo simulations and comparing the actual and nominal coverage probabilities. The Bekker approximation performed well and is much simpler to calculate than the A-R and Bonferroni confidence intervals suggested by Staiger and Stock (1997).

${ }^{25}$ The A-R statistic was proposed by Anderson and Rubin (1949) and has an exact F-distribution in finite samples. Its formula is the following (where $\mathrm{Y}$ is the dependent variable, $\mathrm{X}$ the set of regressors, and $\mathrm{Z}$ the instrument set, and $\mathrm{K}$ the number of instruments):

$$
A R\left(\beta_{0}\right)=\frac{\left(Y-X \beta_{0}\right)^{\prime} Z\left(Z^{\prime} Z\right)^{-1} Z^{\prime}\left(Y-X \beta_{0}\right) / K}{\left(Y-X \beta_{0}\right)^{\prime}\left(I-Z\left(Z^{\prime} Z\right)^{-1} Z^{\prime}\right)\left(Y-X \beta_{0}\right) /(n-K)}
$$

${ }^{26}$ When we include more than one indicator of RCF presence, nothing is robust, probably due to collinearity problems.

${ }^{27}$ When we interact RCF presence with income per capita instead of lagged deposits, we also find significant negative effects. 
${ }^{28}$ We also find strong evidence that RCF presence reduces total lending by RCCs. On average, the RCC loan-deposit ratio in townships with RCFs is 0.77 compared to 0.87 in townships without RCFs. Ratios below one do not imply that credit constraints do not bind because banks have reserve requirements of at least 13 percent. LIMLK-IV estimates (not reported) reveal significant negative effects of RCF presence on the extent to which RCC deposits translate into lending. This is consistent with the model's prediction that with effort, the incumbent may choose to reduce lending if the deposit constraint no longer binds. Since RCFs lend a high percentage of deposits locally, the effect of RCF presence on total local intermediation is ambiguous.

${ }^{29}$ In all regressions, instruments are jointly significant in first-stage regressions but again have relatively low F-statistics. All but one specification pass the Basmann overidentification test at the 10 percent significance level (all pass at the 5 percent level), and most fail the Durbin exogeneity test. The AR statistic finds that RCF presence variables are highly significant in the level regressions but much less so in the difference regressions.

${ }^{30}$ If such requirements substitute for other screening efforts, it is possible that they are negatively rather than positively correlated with the total screening effort of banks. However, we find a strong positive correlation between requirements and loan performance, suggesting that it is reasonable to interpret the requirements as measures of institutional effort.

${ }^{31}$ The Bekker standard errors suggest statistical significance for these reported results, but the AR statistics show much less significance.

${ }^{32}$ An opposite explanation is that in case 2, RCFs take the best borrowers (households) and leave the secondary market (TVEs) to RCCs. However, this story is less likely given the better RCC loan performance under competition despite the prediction that the borrowing pool. 